https://doi.org/10.31874/2309-1606-2018-22-1-25-87

УДК: 130.2: 140.8

\title{
Марія КУЛТАЄВА
}

\section{ФІЛОСОФІЯ ОСВІТИ І ВИХОВАННЯ ТРЕТЬОГО РЕЙХУ:ВИТОКИ, ПОЛІТИКО-ІДЕОЛОГІЧНІ КОНТЕКСТИ ТА КОНЦЕПТУАЛЬНІ КОНСТРУКТИ}

\begin{abstract}
Анотація
В статті аналізуються теоретичні витоки $i$ соціально-політичні контексти становлення філософії освіти і виховання Третього рейху на ши-
\end{abstract}

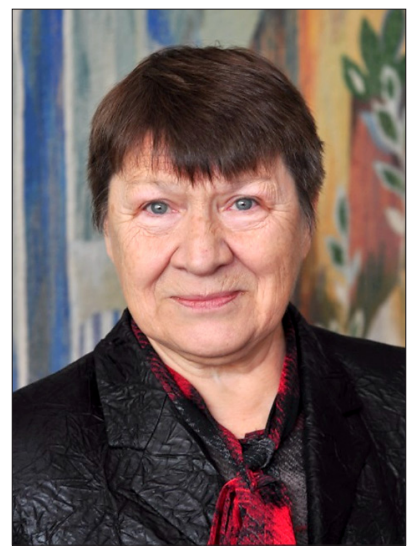
рокому текстологічному матеріалі, а також на основі проведених автором наративних інтерв'ю з включеними спостерігачами иього процесу; здійснюється порівняння націонал-соціалістичної філософії виховання з теорією комуністичного виховання. З'ясовується провідна роль політичної романтики у ретроспективній переорієнтації суспільної свідомості та її освітні і виховні імплікації в рамках, заданих ідеологією націонал-соціалізму. Виявляються особливості конструювання образу «нової німецької людини»на основі ніцшеанства і расової теорії. Здійснена реконструкція тоталітарного педагогічного і філософсько-антропологічного мислення в ідеологічних фреймах націонал-соціалізму. Розкриваються нові аспекти теоретичних розвідок націонал-соціалістичної філософії освіти і виховання, а також педагогічних практик, які домінували у Німеччині у першій половині ХХ ст., обумовлені намаганнями реанімації домодерних уявлень про сенс і призначення освіти, а також спробами рефеодалізації суспільного жмиття на основі постсекулярних ідеологем тоталітарного мислення. Виявляються патології, які виникають внаслідок змін суспільної свідомості і психології соціумів з потужним ілюзіогенним потенціалом, де ідеологія виступає ерзацом релігії. Критично аналізуються концепції національно-політичного виховання та народно-політичної антропології (Е.Крік), політичної педагогіки та проектів реформування наукового виробництва (А. Боймлер), а також системи освіти, орієнтованої на образ фюрера та ідеал «виховної держави». Розкривається внутрішня суперечливість вимог розширення самостійності молоді, домінування функціонального виховання, студентського самоуправління і стратегії самопідключення німецького університету, а також освітньої міфотворчості у вигляді самоствердження виховної держави. Філософія освіти і виховання Третього рейху з ї амбіціями щодо оновлення суспільного життя є модерною кримінальною утопією з обмеженою варіативністю $i$ негативними верифікаціями. 
Ключові слова: філософія освіти, націонал-соціалізм, політичне виховання, політична педагогіка, народно-політична антропологія, раса, студент, школа, університет.

\section{Попередні зауваги}

Третій рейх, як відомо, чинив злочини проти людяності, проголошуючи себе «виховною державою» 3 притаманними їй амбіціями сформувати нову людину і зрештою встановити свій світовий порядок. Однією з основ цього різновиду політико-педагогічної утопії є витримана в дусі націонал-соціалізму філософія освіти і виховання, критичний аналіз якої пропонується нижче. Представлена у цій статті реконструкція тоталітарного педагогічного і філософсько-антропологічного мислення у специфічних політичних і соціокультурних контекстах націонал-соціалізму має за мету поглибити уявлення про теоретичне підгрунтя і практики філософії освіти і виховання, які домінували у Німеччині у першій половині XX ст., а також простежити їх трансформації, що відбувались внаслідок змін суспільної свідомості і психології соціумів з потужним ілюзіогенним потенціалом.

Окреслена проблематика є продовженням розкриття діалектики просвітництва і формування тоталітарного характеру, започаткованого представниками першої генерації Франкфуртської школи Т. Адорно, М. Горкгаймером, Е. Фроммом та іншими ${ }^{1}$. Розкриттю походженню і природи тоталітаризму присвячено чимало досліджень у філософській, історичній і політологічній культурологічній літературі у другій половині минулого століття. Передусім тут треба назвати класичні праці Г. Арендт, Г. Андерса, Ю. Габермаса, Р. Дарендорфа, К. Поппера і багатьох інших. В останні роки пожвавився інтерес до цієї проблематики у філософськоантропологічній, культурологічній та філософсько-педагогічній площині (Г. Гізеке А. Кошорке, В. Мартинкевіч, П. Слотердайк та ін.) .

Цей інтерес обумовлений тим, що в умовах демократії формується «нова культура спогадів» (neue Erinnerungskultur) з визнанням легітимності свідчень так званої «усної історії» (oral history), тобто приватних бесід, спогадів, спонтанних пригадувань².Частину матеріалу, який розглядається у цій статті, також взято з «усної історії», а переклади, що додаються до неї (Г. Цезар та Локі Шмідт), також можна вважати герменевтикою усної історії. Пояснюючи причини суспільного запиту на дослідження різних аспектів націонал-соціалізму, треба зазначити, що

\footnotetext{
${ }^{1}$ Свідченням пожвавлення інтересу українських дослідників до цих праць франкфуртців можуть служити присвячені їм публікації на сторінках журналу «Філософія освіти. Philosophy of Education», 2017, 1(20); 2017, 2(21). Див. також аналіз нотаток М. Горкгаймера до «Діалектики просвітництва» (Култаєва, 2006: 271, 268-269).

${ }^{2}$ Детальніше про це (Schlegelmilch, 2014: 17-19).
} 
рецидиви тоталітаризму час від часу даються взнаки навіть у суспільствах з розвинутою демократією, які успішно подолали його наслідки, не говорячи вже про транзитивні соціуми з радянським минулим. Через це аналіз обгрунтувань освітніх та виховних практик націонал-соціалізму, більш рафінованих, ніж радянські, сприятиме завчасному виявленню тих тенденцій суспільного розвитку, які можуть, за певних обставин, обернутись на тоталітарні. Серед таких обставин, окрім прояву очевидної симптоматики тоталітаризму в Росії, в окупованих нею частинах України, в Північній Кореї та у деяких інших країнах, також треба назвати останню хвилю численної спонтанної міграції, яка стала викликом для об’єднаної Європи і випробуванням на міць іiї засадничих цінностей вже не рівні декларацій, а у площині реальних дій, що передбачає подолання національних егоїзмів. Пошуки відповіді на такі виклики ускладнюються тим, що нова генерація європейців, призначених бути охоронцями духовних скарбів європейської цивілізації, не має стійкого імунітету від спокус тоталітаризму ${ }^{1}$.

Контекстуально-критичний аналіз філософії освіти і виховання Третього Рейху певною мірою розкриває механізм дії таких спокус, вказуючи на небезпеку навіть часткової реанімації ідей з тоталітарним присмаком. Потенційна загроза, що походить від них, не в останню чергу виникає через конституювання так званих суспільств сингулярності у їх закритих версіях і пов’язаних з цим непередбачуваних наслідків самоствердження національних культур в ускладнених багаторівневих процесах глобалізаціїㄹ. На перший погляд, тоталітарні суспільства діаметрально протилежні сингулярним, бо підпорядковуються логіці загального. Але патологічні домагання тоталітарних соціальних конструктів на визнання власної унікальності і неперевершеності, будь то футуристичне натхнення будівників комунізму або екстаз очищення та «справжньої» реінкарнації німецької нації, у парадоксальний спосіб також роблять такі суспільства сингулярними, щоправда, у негативному сенсі - як нагадування про руйнівні наслідки національного нарцисизму і досвід реалізації настанов кримінального утопізму.

Розгляд націоналістичних ідей і націоналістичних філософськоосвітніх і філософсько-педагогічних розвідок має свої методологічні складнощі. Як зазначає Н. Еліас, їх не можна досліджувати за моделлю «історії ідей», бо це «найпотужніша соціальна система віри 19-го -20-

${ }^{1}$ Р. Дарендорф дуже влучно охарактеризував зміст таких спокус: «Фашизм спокушав згуртованістю і лідерством», а «комунізм - згуртованістю і надією» (Dahrendorf, 2006: 26,33).

${ }^{2}$ Ці тенденції і відповідні загрози детально аналізуються А. Реквітцем (Reckwitz, 2017: 426-427). 
го століть» і потребує звернення не тільки до історико-філософської та історико-педагогічної літератури, а й паралельного аналізу суспільних трансформацій, які генерують і підтримують націонал-соціалістичні теopiï (Elias, 1992: 194). Спроба такого аналізу, обмеженого обсягом журнальної публікації, пропонується нижче. Там, де у тексті статті є позначка «цитування за», це означає не перецитування, а посилання на праці, де означені документи наводяться повністю як додаток.

До усього, сказаного вище, треба також додати, що модерні тоталітарні суспільства XX-го століття, як націоналістичні, та й інтернаціональні, звичайно пов'язують зі становленням індустріального суспільства, що супроводжується спробами реставрації феодальних моделей життєтворчості і організації суспільного життя, його суцільної раціоналізації. Тим не менш пізній Модерн керується не тільки логікою інструментального розуму, притаманного індустріалізму, а й логікою ірраціонального мислення. Обидві логіки, як буде показано нижче, присутні у філософії життя кінця XIX- початку XX століть, яка визначила філософсько-педагогічне теоретизування ідеологів націонал-соціалізму. Його основні настанови, спрямування та образ людини у цілому були сформульовані ще задовго до Першої світової війни (В. Дільтей, Л. Клагес, Ф. Ніцше, Г.С. Чемберлен та ін.) ${ }^{1}$. У часи Ваймарської республіки ідеї декадансу і волюнтаристичні проекти реставрації германської величі вже конкурували з гуманістичними ідеалами освіченої буржуазії. Остання займала демонстративно аполітичну позицію, але тим не менш своїм консерватизмом впливала на суспільні настрої свого часу і зробила чималий внесок до «революції справа», задаючи хибні світоглядні орієнтири молоді. Найбільш уразливими перед спокусами націоналістично препарованої філософії життя і відповідної інтерпретації німецької класичної філософії (Кант, Фіхте, Гегель) виявились студенти, які зі зміною умов професійного самоствердження відчували себе занадто невпевнено у нових соціокультурних контекстах, але були організовані у студентські спілки. Економічна криза, безробіття, реальність національного приниження Німеччини змушували молодь усіх верств населення (студентів, колишніх солдатів, робітників, службовців, творчу інтелігенцію) об’єднуватись у боротьбі за кращу долю в націонал-соціалістичний рух, де важливим інструментом згуртування мав стати «новий світогляд» і відповідна філософія освіти і виховання, яка мала підготувати підгрунтя для «тотальної мобілізації» підростаючого покоління на засвоєння змісту цього світогляду і на практичну реалізацію його настанов.

\footnotetext{
${ }^{1}$ Див. детальніше про теоретичні джерела та богемно-мистецькі імпульси у формуванні ідеології націонал-соціалізму у фундаментальному дослідженні В. Мартинкевича (Martynkewicz, 2011: 89-111).
} 
На відміну від комуністичної версії тоталітаризму з притаманною їй вірою у світову революцію та опорою на інтернаціоналізм у здійсненні історичної місії пролетаріату, німецький націонал-соціалізм виходив з унікальності німців, які мали усвідомити свою ідентичність, відновитись та відродитись через повернення до своїх витоків. Цей рух не мав класового підгрунтя і чітко визначеного класового гегемона, бо ототожнював себе 3 народом, апеляції до якого містяться в усіх ідеологемах націонал-соціалізму. Стратегія національного самоствердження у Німеччині спиралась на ніцшеанську інтерпретацію ідей надлюдини, волі до влади та на міфологему повернення того ж самого, актуалізовані у філософії життя. Національна ідея як чинник консолідації суспільства формувалась у даному випадку на основі історичної міфотворчості, яка не просто продукує смисли політичної романтики, а й спонукає їх втілити, створити нову німецьку дійсність делегуючи цю авантюрну справу молоді ${ }^{1}$.

Як зазначає П. Слотердайк, німецький націонал-соціалізм, «так само, як і радянськотизм (Sowjetismus), був лише поквапливою імпровізацією, швидкий розпад якої було закладено ще у модусі ії гарячкового створення. Гітлеризм фактично був формою політичного сомнамбулізму, який з першої хвилини захоплення влади прийняв дозу суїцидального азарту. Фактично це був експеримент з метою знайти відповідь на питання, чи здатні держави на самогубство разом зі своїми суспільствами» (Sloterdijk, 2014: 182). Історія, як відомо, дає стверджувальну відповідь на це питання і через це змушує аналізувати такі патології у різних аспектах, в тому числі й у філософсько-педагогічному.

Отже, не дивно, що саме політична романтика з притаманною їй силою ініціативи та потужною утопічною енергетикою виступає тією матрицею, на якій нашвидкоруч вибудовується еклектична філософія освіти і виховання, системотворчими елементами якої стають расова теорія та міфотворчість політичної романтики, яка дозволяє ситуативно жонглювати концептами нового і старого, життя і смерті, героїзму і злочину. Розгляд філософії освіти і виховання Третього рейху крізь призму політичної романтики дозволяє також дещо відійти від стадіального схематизму іiі реконструкцій і зосередити увагу на практичних імплікаціях тоталітарного філософсько-педагогічного мислення. Виходячи з цього, до статті як розширений фактологічний матеріал додаються спогади включених спостерігачів зазначених процесів.

1 Загальновідомо, що ідеологи Третього рейху відводили молоді та їі вихованню вирішальну роль в усіх перетвореннях і призначали здебільшого молодих людей на ключові пости у державних органах. Більшості так званих «старих бійців» (alte Kämpfer) було ледь за 30 років. 


\section{Політична романтика та її політико-педагогічні імплікації}

Поняття «політична романтика» $є$ досить широким за своїм смисловим обсягом. Воно позначає передусім амбівалентні настрої суспільства, яке із сумом прощається зі старим ладом і водночас наповнено сподіваннями, вірою і надію на реалізацію нових суспільних ідеалів або принаймні на наближення до міражів на самому обрії замріяної свідомості. Найбільш лапідарне і змістовне іїі визначення дає П. Тілліх: «Політична романтика - це зустрічний рух, спрямований проти пророцтва і просвітництва на грунті духовного і суспільного становища, визначеного просвітництвом. ... Політична романтика має дві форми: вона може бути консервативною і революційною. Обидві форми можуть поєднуватись у різноманітний спосіб, але й суперечить одна одній» (Tillich, 1980: 34). Через це виникають парадокси політичної романтики. Вона змушена посилатись на універсалістську етику, заперечуючи загально значущі етичні принципи, тим самим стверджуючи подвійну мораль: для своїх і чужих. Власні ірраціональні настанови їй доводиться обгрунтовувати раціонально, що правда за допомогою догідливого інструментального розуму ${ }^{1}$. Усе це торкається також ідеї соціалізму, яка присутня у специфічно трансформованому вигляді у німецькому фашизмі. Ця ідея обумовлює домінування у ідеології і практиках націонал-соціалізму революційної форми політичної романтики з ії деструктивними інтенціями, педагогічним натхненням та завзятістю у процесі формуванні нової людини, а також селекції людського матеріалу, придатного до обробки педагогами Третього рейху. Політична романтика в усіх її різновидах тісно пов'язана з психополітикою та педагогікою, використовуючи їхні здобутки у пошуках найбільш ефективних шляхів, форм і методів створення надлюдини германського зразка. Рух націонал-соціалізму, керований політичною романтикою, вже на першому владному віражі зухвало виходить на зустрічну смугу і безжалісно трощить вишуканий, але не відремонтований засіб пересування гуманістичної педагогіки, яка на початку XX-го століття виконувала свою кропітку роботу над подоланням нерівності в освіті та залученням дитини до скарбів духовної культури людства.

В ідеології націонал-соціалізму політична романтика виконує не тільки функцію генерування футуристичного ентузіазму, як це має місце у комуністичній ідеології, а й реанімує дух німецької давнини, вчить молодь розмовляти з тінями забутих предків, отже, робить чималий внесок до світоглядного виховання підростаючого покоління за ідеологічно визначеними параметрами, привчаючи молодь жити у міфі і для міфу.

\footnotetext{
${ }^{1}$ Докладний опис таких парадоксів див: (Tillich, 1980: 34, 90-92).
} 
Тим самим вона сама в окреслених соціокультурних контекстах трансформується у політичну філософію та політичну теологію з можливостями освітніх і виховних репрезентацій. Засадничі принципи цієї суто німецької теоретичної форми політичної романтики взято з філософії життя та ії екзистенціальних, філософсько-антропологічних трансформацій, а також з літературних версій національно або містично орієнтованого романтизму та символізму ${ }^{1}$. На зламі XIX-XX століть ця строката світоглядна суміш застосовувалась як духовна основа стратегії латентної рефеодалізації індустріальних суспільств.

Світоглядне ядро політичної романтики утворюють міф про походження з метафорикою землі та крові, а також статичні і динамічні образи політичних друзів та ворогів (Tillich, 1980: 24-25). На відміну від раціональних політичних стратегій, політична романтика апелює до несвідомого, іiї настанови насичені еротичними смислами, які роблять привабливою навіть смерть, що було не менш важливим для рекрутування молоді до лав бійців націонал-соціалістичного робочого фронту ${ }^{2}$.

Ще до початку націонал-соціалістичного руху політична романтика сприймалась як альтернатива зародкам демократії у Німеччині та Австрії. Саме вона, конкуруючи із приземленими профспілками, стала неформальною школою політичного виховання молоді, передусім у невеличких університетських містах та німецькій глибинці. В одному з багатьох наративних інтерв'ю, проведених мною з Г. Цезар (дівоче прізвище Розендаль) та іiї колишньою однокласницею Г. Бохман (дівоче прізвище Ренфорд) упродовж 1990-2002 pр., було відмічено, що в селах та невеликих містах Вестфалії (Вердоль, Альтена, Нахрод, Віблінгверде та ін.) ще у 20- рр. під впливом настанов консервативної політичної романтики населення утворювало групи самопомочі (Selbsthilfe) для охорони садів і майна від набігів люмпенізованих пролетарських угруповань за принципом «друг-ворог». Пізніше ті ж самі групи самопомочі під впливом революційної романтики були добровільно реорганізовані в загони штурмовиків (SA). Акцентування у їхніх діях принципу самоорганізації

\footnotetext{
${ }^{1}$ Навіть секулярна трансформація середньовічної теологічної ідеї царства Божого на землі тут перетворюється на політичну програму розбудови Третього рейху як виховної держави. В. Мартинкевич у цьому зв'язку звертає увагу на той факт, що поняття «Третій рейх», перш ніж стати у 1918 р. гаслом так званої «Консервативної революції, а у 1933 р. політичною реальністю, набуло поширення вже наприкінці XIX ст., а у 1915 р. Т. Манн виголосив романтизовану формулу нової німецької держави (Третього рейху) як «синтез влади і духу» (Martynkewicz, 2011: 237).

${ }^{2}$ Після приходу Гітлера до влади німецький робочий фронт (die DAF - die deutsche Arbeitsfront), створений у 1933 р., замінив собою профспілки і спілки молодих робітників, а Перше травня було проголошено «Днем національної праці» $\mathrm{i}$ вихідним (Kunkel, 2014: 106).
} 
як ініціативи «знизу», тобто від «народу» і почуття свого обов’язку перед ним, закріплювало хибне уявлення, що тоталітарно орієнтована політична романтика з іiі спокусами і містифікаціями є формою «справжньої» демократії.

Розглянемо більш детальніше теоретичні обгрунтування цієї позірної форми демократії та іiі філософсько-педагогічні імплікації. Так, К. Шмітт, один із провідних теоретиків політичної романтики, ще наприкінці 20-х і початку 30-х рр. минулого століття запропонував контрфактичну версію «справжньої» демократії, що грунтується на міфі про походження і начебто виводиться із глибин німецького духу, нормативні характеристики якого визначаються досить схематично. Зрештою політико-антропологічні розвідки Шмітта обернулись апологією націонал-соціалістичного руху і відігравали далеко не останню роль у політичному вихованні німецької молоді. Так звана «справжня» демократія, за Шміттом, - це «ідентичність тих, хто править, і тих, ким правлять» (Schmitt, 1979: 20, 35). Західні ж демократії, передусім американську, британську і французьку, він, за логікою германоцентризму, вважав організаціями або механізмами, які перешкоджають проникненню до глибинних основ політичного і народного життя. Така концептуалізація демократії в опціях політичної романтики з етнічним присмаком дозволяла розширити пропагандистський арсенал націонал-соціалізму на зразок тверджень про «живий демократизм Третього рейху», який позиціонував себе як «виховну державу» (Erziehungsstaat). Але держава, навіть виховна, якщо розглядати ії у площині політичної романтики, є лише одним з елементів «політичної єдності», до якої, за Шміттом, належать також рух і народ. Вирішальну роль тут відіграє рух, який виступає посередником між державою та народом, перетворюючи останній з неполітичного у політичний елемент цієї тріади. Саме на цій підставі націонал-соціалістичний рух визначається у Шмітта як демократичний (Schmitt, 1933: 112). У ті часи це знаходило відгук серед широких верств населення, яке сподівалось на диво національного відродження німців.

Навіть такий видатний письменник і гуманіст як Т. Манн, осмислюючи уроки Першої світової війни з позиції «аполітичного інтелектуала», поділяв, хоча й недовго, ідею щодо особливого шляху і призначення німців. Вони, на його думку, повинні були не копіювати чужий досвід, а створити свою особливу демократію у вигляді «народної держави» як «сконцентрованої форми буття німецького духу». Реально ж існуюча демократія, тобто ііі успішний досвід у Франції, Великобританії та США, у ті часи негативно сприймалась романтично налаштованими німецькими інтелектуалами. Вони вбачали у ній тиранію політики, наслідком якої стає конституювання «несправжньої дійсності». Наведе- 
мо аргументацію Т. Манна: «Демократія означає панування політики. У ній не існує нічого, куди б не втручалась політика, вона усюди - у мисленні, творчості, житті» (Mann, 2009: 315). Німці ж, на його думку, повинні мати свої національні політичні інституції, керуючись своїм власним розумінням свободи, на відміну від західних «механічних» демократій, у яких права людини начебто мають «холодно-абстрактний зміст». Т.Манн пропонує «онімечить» поняття демократії і свободи, акцентуючи в них семантику «народного» $\mathrm{i}$ «нерівності». Також він вказує на відмінність німецького державного соціалізму (Staatssozialismus) від його марксистського розуміння, який грунтується на ідеї рівності та на правах людини (Mann, 2009: 291-293).

Разом з ідеєю народної, або соціалістичної, держави (völkischer Staat, Staatssozialismus) у 20-х pр. поширюється та набуває популярності ідея фюрера і відповідно - вимога добровільного слідування народу за політичним лідером. Згодом, у роки самоствердження націонал-соціалізму і державотворення такий лідер починає клонуватись і вирощуватись у школах молодих лідерів нового типу. Про такі школи та їхню освітньо-виховну неспроможність йтиметься нижче. Тут же звернемо увагу на такий момент. Романтизація образу фюрера ще задовго до появи на політичній арені Гітлера нагадувала езотеричні практики навіювання і масового гіпнозу. Але такі практики не знайшли б широкої підтримки серед різних верств населення Німеччини, якби не було етики служіння державі та ідеалізації лідерів, закріплених у соціальній психології німців, що не заважало їм бути аполітичними у світі повсякденності. ${ }^{1}$ Аполітичність навіть до середини 30-х р. була ознакою хорошого тону у німецьких навчальних закладах різного рівня і різної спеціалізації, коли ще існували альтернативні форми освіти і різні стратегії виховання підростаючого покоління, що згодом полегшило процес денацифікації у Німеччині.

Щоб підкріпити цю тезу аргументативно, звернемось до матеріалів, наданих включеними спостерігачами цих процесів. Отже, Г. Шмідт, ексканцлер ФРН та колишній учень школи Ліхтварка у Гамбурзі, так оцінює стан політичного виховання у цьому закладі: «Політичне виховання широких верств населення у ті роки заслуговує лише на незадовільну оцінку. Люди взагалі не мали жодного уявлення, що таке держава. Наприклад, у школі я жодного разу не почув слова «демократія». Я зіткнувся $з$ ним вперше тільки у нацистській пропаганді. Оскільки нацисти

${ }^{1}$ М. Горкгаймер слушно розглядає цю тенденцію як процес перетворення «автономії індивіда на його гетерономію», що є наслідком ствердження «раціональної форми самозбереження через добровільне підпорядкування, індиферентне як до політичного, так і до релігійного змісту» (Horkheimer, 1942: 332). 
розповідали, яка це мерзотна річ, я одразу збагнув: мабуть, тут щось не так, хоча не мав жодного уявлення про те, чим є демократія насправді. ... Також мені були невідомі поняття правової держави, природного права, прав людини. ... Але у школі Ліхтварка я навчився працювати і самостійно робити висновки. До речі, це була особлива школа, ліва за своєю тенденцією, в ній більшість вчителів були ідеалістичними соціал-демократами або ж - ідеалістичними комуністами. Але ніхто не займався 3 нами політичним вихованням. Важливими були музика, мистецтво, а найголовніше тут вчили самостійно працювати» (Schmidt, Stern, 2010: 87-88) ${ }^{1}$. Така шкільна ідилія у часи Веймарської республіки була радше винятком, а не правилом. Навіть у родинному вихованні у ті часи домінували здебільшого настанови конвенціональної етики, практикувались й тілесні покарання як інструмент дисциплінування учнів (Züchtigung). У народних школах порушення дисципліни також зазвичай карались тілесними екзекуціями. У наративних інтерв'ю, проведених мною 3 К. Еллерманом (Люденшайд, 2015-2017 рр.), він особливо підкреслював той факт, що неписаний закон честі учня забороняв їм скаржитись на вчителів вдома. Передбачуваною була й реакція батьків нижчих верств населення на тілесне покарання дитини у школі - вони повторювали цю практику тими ж самими методами, виховуючи слухняність дітей у рольовій реальності підлеглого. Дитина тут не мала ніяких прав, хоча у Європі після Руссо і Канта романтичний образ дитини був виховним орієнтиром у значної частини середнього класу. Зміст родинного виховання, відповідно до цього образу зводився до формування культури поведінки, засвоєння морально-етичних норм, надання стимулів для духовного розвитку. Усе інше мали забезпечити церква, школа та університет. Салон і суспільство для цього прошарку населення були синонімами ${ }^{2}$. Отже, дефіцит політичного виховання давався взнаки в усіх освітніх інституціях і в усіх верствах населення німецького суспільства окресленого історичного періоду.

Політична романтика легко заповнила цю прогалину, адже вона начебто і не була політичною, бо походила із глибин «народної душі»

\footnotetext{
${ }^{1}$ Школа Ліхтварка була втіленням ідей директора Гамбурзької мистецької галереї Альфреда Ліхтварка (1852-1914) щодо естетичного виховання дітей нижчих верств населення та формування самостійної і відповідальної особистості. Тут практикувалась коедукація, окрім загальноосвітніх предметів, викладались основи економіки, праця та музика. Детальніше про руйнацію школи Ліхтварка у часи панування націонал-соціалізму див. у наведених нижче спогадах Локі Шмідт, дружини та однокласниці Г. Шмідта, екс-канцлера ФРН.

${ }^{2}$ Саме це відображує назва монографії В. Мартинкевича «Салон Німеччина. Дух і влада 1900-1945», присвячена аналізу духовної ситуації цього історичного відрізку (Martynkewicz, 2011).
} 
(Volksseele), одного з центральних понять ідеології націонал-соціалізму. До того, ж у середовищі німецьких робітників не було такої віри у всемогутність марксизму, як у царській Росії, а пізніше в СРСР. Протестантська етика і дух капіталізму відкривали німцям цілковито інші перспективи самоствердження. Але якщо російські марксисти хотіли сформувати нову людину і цілковито інше суспільство через тотальне і примусове перетворення усіх на пролетаріат, то націонал-соціалісти переслідували мету пробудження німецького духу, вбачаючи у ньому неабиякий модернізаційний потенціал, розкриття якого вимагало «тотальної мобілізації», «битв» $\mathrm{i}$ «священної війни задля миру», що проголошувалось умовами самореалізації німецької нації. Ці вимоги згодом увійдуть до переліку ключових слів ідеології Третього рейху.

Міф про походження і расову вищість гальмував критичну саморефлексію німців, дезорієнтуючи національну самосвідомість і практики національно-патріотичного виховання. Порівнюючи на основі узагальнень історичної соціології національні автопортрети (Selbstbild der Nation) німців та англійців, Н. Еліас зазначає, що «німцям завжди бракувало британської реалістичної самооцінки своїх національних досягнень і культурної своєрідності, у німців вони значно перебільшувались, а їхня самосвідомість вибудовувалась на колективних фантазіях про переваги над усіма іншими народами світу, через це утворювалась прірва між національним ідеалом і національною дійсністю. ... Англійський патріотизм не був романтичним. Англійці також, як і німці, часто задля його посилення звертались до минулого. Але у їхньому образі Англії й дотепер минуле не відірване від сучасного. Минуле не сприймається як щось набагато величне за сьогодення» (Elias, 1992: 419-420). Отже, перевагою англійців було чітке і позбавлене ілюзій уявлення щодо своєї ідентичності. Їхнє національно-патріотичне виховання не припускало колективного марнославства і органічно вписувалось у програму «виховання джентльмена», де самоповага і повага до співвітчизників незалежно від раси і соціального статусу відіграють далеко не останню роль. Повертаючись до характеристики німців, Еліас робить висновок, що німці мали досить нечіткі уявлення про себе і свою країну, керуючись власною міфотворчістю та героїзацією повсякденності. Суто німецьким, за його спостереженнями, завжди залишався «світогляд» (Weltanschauung) як особливий різновид віри: «Німці відчували, що бути німцем є цінністю (Wert), але у чому полягає ця цінність, - відповідь на це була занадто розмитою. Думки щодо цього дуже розбігались. У минулому, коли Нiмеччина була слабкою, національна гордість представників середнього класу, який підіймався у країні, грунтувалась на спільних досягненнях у науці, літературі, філософії та музиці, одним словом, трималась на 
культурі. ... Само слово «Німеччина» для німецького вуха пробуджувало асоціації з чимсь надзвичайним, з харизмою, що межувала зі святістю. У нормальному житті те, що називається «бути німцем», майже не накладало на людину жодних зобов'язань, хіба що на можновладців та авторитарних особистостей» (Elias, 1992: 420-421). Але в екстремальних ситуаціях національного приниження, як це було після поразки Німеччини у Першій світовій війні, на цьому грунті формується специфічна соціальна психологія ресентиментально налаштованих мас, які жадають реваншу як компенсації за крах своїх романтичних мрій та прагматичних сподівань на краще життя, пов'язаних безпосередньо з національним піднесенням. М. Горкгаймер, характеризуючи ці процеси, вбачає в них також наслідки поширення параноїдального мислення: «Німеччина ... виявилась чудовим розплідником параної. Німецьке суспільство було організоване так, щоб продукувати параноїдальне мислення і стимулювати його поширення» (Horkheimer, 1987:355). Особливо це захоплювало молодь, яка мала схильність до мрій та мислення бажаннями (Wunschdenken), отримане у спадок від школи німецького національного романтизму.

Романтичні настрої німецької молоді, особливо студентства, посилювали уявлення про війну як джерело духовного, душевного і тілесного оновлення, разом з гіпертрофованим почуттям честі. Формування етосу середнього класу у німців традиційно закладалось у студентські роки. Якщо британці, як вже зазначалось вище, опікувались формуванням моралі і габітусу джентльмена, то німці відстоювали архаїчне розуміння гідності і честі, відтворюючи у практиках дуелей середньовічні стереотипи лицарської поведінки і функціонального виховання дрібних феодалів. Дуель була рудиментарною складовою моделей поведінки німецьких офіцерів, а також студентів у кайзерівській Німеччині, а після Першої світової війни вона, а ще більше збережені смисли цієї історично віджитої форми розв'язання конфліктів виступали засобом підтримування бойового духу і форми німців ${ }^{1}$. Як слушно вказує Еліас, між бійкою селян або робітників та дуелями вищих верств населення, чи такими, що їх імітують (студентами, політиками), існує схожість, бо обидві є «приватними війнами» (Elias, 1992: 94). Але тут також має місце й принципова відмінність. Адже у першому випадку йдеться про зіткнення без правил та норм. Бійка завжди спонтанна і не має власної естетики. Вона брутальна. Певні естетичні, а в окремих випадках й героїчні риси, зазвичай надаються їй заднім числом, у спогадах і мемуарах, але здебільшого про неї забувають. Дуелі ж, навпаки, треба вчитись, бо вона є розтягнутою у

\footnotetext{
${ }^{1}$ Показово, що практика дуелей була поширена також й у царській Росії, а іï̈ збережені смисли ще й досі відчутні у зовнішній політиці РФ.
} 
часі естетизованою ритуальною дією з чіткими правилами. Важливим у ній є не демонстрація сили чи влади або миттєве розв'язання конфлікту у суб'єктивному сенсі, а збереження честі і сатисфакція. У дуелі завжди присутні елементи театралізації та естетизації. Ці елементи почасти зберігаються у виховних практиках націонал-соціалістичного руху, але повною мірою актуалізуються у часи самоствердження німецького фашизму як політичного режиму, коли реанімуються образи лицарів та дуелянтів. Щоправда, це стилізується під зіткнення друга і ворога або трансформується у рольову реальність активістів націонал-соціалістичного руху та в образи Солдата і Робітника, які також романтизуються i набувають статусу виховних ідеалів. ${ }^{1}$

Політико-педагогічні імплікації політичної романтики мають досить широкий діапазон. У пізньому Модерні, особливо на початку ХХ століття, романтичні сподівання щодо руйнації «старого світу» супроводжувались мріями про нову державу, але не у вигляді статичних утопічних ідилій, як у ранньому Модерні, а у динамічних проектах активних соціальних перетворень і радикальних змін національного буття. На їх основі у Німеччині після Першої світової війни виникає нова інтерпретація ідеї народної «національної демократії». Така інтерпретація посилила привабливість ідеології націонал-соціалізму як конкретизації саморозуміння пересічних німців у сконструйованих ними проектах власного національного стилю життя. Пов'язані з цим ілюзії далеко не в останню чергу приваблювали широкі верстви збіднілого населення, передусім студентську молодь, яка жадала національного оновлення і мріяла про «народну державу».

Треба зазначити, що поєднання держави і народу, пересічного німця і влади ще в 20-х рр. минулого століття розглядалось або з позицій неогегельянства, або у більш привабливій для романтизованої свідомості оптиці кантіанських трансформацій на зразок культурної та соціальної антропології, також екзистенціалізму, але в обох випадках була присутня політико-педагогічна або культурно-педагогічна складова. Нерідко ці дві лінії поєднуються, як це має місце у Е. Шпрангера, який поділяв проаналізовані вище погляди Шмітта щодо виховного потенціалу політичної романтики. При цьому у своїх міркуваннях щодо нового німецького освітнього ідеалу він акцентує важливість збереження вітальнобіологічного підгрунтя для культурно-виховного процесу. «Саме вітальний базис, - підкреслює він, - дозволяє визначати ідеали і виконувати

1 Значний внесок до популяризації і нової інтерпретації образу Робітника зробив Е. Юнгер своїми працями «Тотальна мобілізація» (Берлін, 1930) та «Робітник. Панування і образ» (Гамбург, 1932). Більш детально про сигнальне значення цих праць див. у монографії М. Леске (Leske, 1990: 73,77). 
обов’язки, коротко кажучи - забезпечує збереження моральних сил... . Виходячи з цього, можна сформулювати найпершу суттєву вимогу до освітнього ідеалу сучасності: треба виховувати так, щоб зберегти і примножити вітальне здоров'я підростаючого покоління (Spranger, 1928: 18-19). Цей висновок кілька роками пізніше стане однією із засадничих тез філософії освіти і виховання Третього рейху, хоча сам Шпрангер дистанціювався від ідеологів націонал-соціалізму вже у 1933 р. ${ }^{1}$ Семантика здоров'я і тілесності, як буде показано нижче, є однією з домінантних у філософії виховання Третього рейху. Вона окреслює філософсько-педагогічні імплікації расової теорії, яка є основою політичної філософії націонал-соціалізму.

\section{Культурно-антропологічні обґрунтування расової теорії та їх освітні та виховні наслідки}

Расова теорія Третього рейху як основа його кримінального утопізму і відповідних політико-виховних практик також у цілому сформувалась ще до широкого розгортання націонал-соціалістичного руху, але органічно вписалась у їі міфотворчість, а зрештою стала системо-утворюючим чинником . Одним із іiі джерел є біологізаторська теорія расового детермінізму і нерівності рас Ж.А. Гобіно. Ця теорія наприкінці XIX ст. була переосмислена у дусі гегелівської діалектики Г.С. Чемберленом, британським германофілом з біологічною освітою. У його теорії значну роль відіграє категорія становлення (Werden), а раса пов'язується з народом і культурою. Погляди Чемберлена, який не мав філософського вишколу, були надзвичайно еклектичними і суб’єктивістськими, але знайшли багато прихильників у 20-х рр. минулого століття, передусім в салонах Відня і Мюнхена.

Аналізуючи особливості расової теорії Чемберлена, В. Мартинкевич зазначає, що він привніс до поняття раси динаміку, вбачаючи в ній не даність, а становлення, це торкається також й понять «німецькість (Deutschtum), кров, народ» (Martynkewicz, 2011: 117). На думку Чемберлена, саме динамізм надавав німецькій нації перевагу перед іншими, бо принципова незавершеність процесу іiі становлення як нордичної раси у єдності тілесного і культурно-духовного вимагала від неї постійної роботи над власним удосконаленням, бо чим більше вона наближалась до нордичного ідеалу, тим ретельніше мало відбуватись іiі очищення. Ця

${ }^{1}$ Однією з причин конфлікту Шпрангера зі владою стало призначення не його, А. Боймлера на посаду директора новоствореного Інституту політичної педагогіки, бо ідеологи Третього рейху не пробачили Шпрангеру його виступів проти «обожнення народу» (Leske, 1990: 222). 
ідея, щоправда гранично абстрактно і без біологічного підгрунтя, була висловлена ще Фіхте у його «Промовах до німецької нації,, де інструментом іiі формування проголошувалось виховання, яке покладало на німецьку націю обов'язок вести за собою інші народи, яким, за фіхтеанськими мірками, бракувало досвіду такого формування (Култаева, 1999: 9-10). У Чемберлена, на відміну від гуманістичної утопії Фіхте, місіонерське розуміння нації замінюється на не менш місіонерське призначення раси. Окрім того, поняття раси у Чемберлена більш пов'язане з ідеєю спадковості, а доцільність його застосування у теорії і практиках виховання обгрунтовується у дусі євгеніки.

Поєднати ці ідеї на основі тези про перевагу нордичної раси спробував Г.Ф.К. Гюнтер, філолог за освітою і головний расознавець Третього рейху, який виступав проти змішення рас та урбанізації Европи, намагаючись тим самим «оздоровити» дух континенту через поширення на ньому нордичної раси, яка сама, за його теорією, потребувала очищення і ствердження. Біологізаторська складова його расової теорії надає їй флер науковості, щоправда позірної. В ній одно з центральних місць займають поняття спадковості і відбору, але останній мислиться вже не як природний, а як політично скерований на виведення нової людини. Отже, «біологічним» у расовій теорії є тільки біологічна аналогія, застосована до людинотворчого потенціалу культури, освіти і виховання.

На підставі своїх расознавчих студій Гюнтер запропонував типологію рас і суб’єктивістсько обгрунтоване право німецького народу проводити цілеспрямовану расову політику з метою забезпечення расової чистоти арійців і вирощування надлюдини ${ }^{1}$. При цьому приналежність до тієї чи іншої раси, за Гюнтером, мала встановлюватись за тілесно-духовними ознаками ${ }^{2}$. Парадокси процедур емпіричного виявлення приналежності до нордичної раси через вимірювання черепу і встановлення типології рас описує вже згадана раніше Локі Шмідт в своїх спогадах, які додаються до цієї статті. На питання «спадковість чи виховання» Гюнтер схиляється до віддання пріоритету генетиці і пропонує рекомендації щодо збереження чистоти роду (Sippenpflege). Впровадження таких вимог у педагогічний процес описує Г. Цезар у додатку до цієї статті.

${ }^{1}$ Див.: Günther H.F.K. Volk und Staat in ihrer Stellung zu Vererbung und Auslese. München: J.F. Lehmann-1933. Показово, що в Росії видаються і користуються попитом праці Гюнтера (Гюнтер, 2005).

${ }^{2}$ Гюнтер у співавторстві з Ойгеном Фішером написав книгу «Німецькі голови нордичної раси» (1927), за якої в школах Німеччини встановлювалась расова приналежність учнів, що принижувало їхню гідність і гідність їхніх батьків. 
Вчення Гюнтера, співзвучне міфотворчості А. Розенберга, намагалось підвести квазінауковий базис під політику антисемітизму 1 . Як зазначають М. Горкгаймер і Т. Адорно, ідеологія націонал-соціалізму зробила з євреїв уособлення єдності внутрішнього і зовнішнього ворога (Horkheimer, Adorno, 1987: 214-215). Антисемітизм і расова теорія органічно вписуються у тоталітарні плани реалізації величі Німеччини. На відміну від тоталітарних соціумів, у демократичних суспільствах загрози таких патологій більш-менш успішно мінімізуються. Як зазначає відомий історик Ф. Штерн, консультант колишнього президента США Б. Обами, у 30-х pp. в елітарних університетах США панував прихований антисемітизм, особливо відчутний у гуманітарних науках, де «кількість єврейських студентів утримувалась у надзвичайно вузьких рамках. Але усе це стрімко змінилось одразу після Другої світової війни» (Schmidt, Stern, 2010: 225). Теж саме можна сказати і про ФРН. Показово, що у країнах з комуністичною ідеологією прихований антисемітизм існував аж до їхнього розпаду попри вимоги виховання молоді в дусі інтернаціоналізму. Це також свідчить про принципову значущість образу внутрішнього і зовнішнього ворога для конституювання тоталітарних суспільств, а також для визначення стратегій освіти і виховання підростаючого покоління у цих країнах.

Повертаючись до німецьких реалій доби Третього рейху як рамкових умов освітніх і виховних практик націонал-соціалізму, зауважимо, що антисемітизм тут супроводжувався надмірним акцентуванням національних традицій, як німецьких, так і єврейських, що призводило до мимовільного відтворення нацистськими бонзами у своїй поведінці і манері говорити певних рис єврейських гендлярів. Так, за спостереженнями М. Горгаймера і Т. Адорно, досить часто Геббельс виступав перед масами як «єврейський агент, якого він сам вимагав знищити» (Horkheimer, Adorno, 1987: 215).

Надмірне акцентування німецькості (Deutschtum) також справляло враження театральності. Зміни, що відбувались у 30-х рp. у габітусі частини академічної спільноти з метою посилення у ньому народного елементу, несли на собі відбиток карикатурності і зрештою сигналізували про вторгнення домодерної сільської культури у модерний урбаністичний простір, що загрожувало освіті, передусім університетській. Так, М. Гайдеггер, за свідченнями його учнів, спогади яких наводяться нижче, приходив до університету зазвичай у вбранні, стилізованому під строї шварцвальдського селянина з фольклорною вишивкою. Студентам з німецької глибинки таке подобалось, студенти ж з великих міст і $з$ єврейських асимільованих родин вважали це дивакуватим.

\footnotetext{
${ }^{1}$ Гюнтеру належить антисемітська праця «Заборона змішаних шлюбів з євреями»
} (Günther, 1933) 
Дещо забігаючи наперед зазначимо, що публікація «Чорних зошитів» Гайдеггера надала поштовх не тільки новому обговоренню громадянської позиції цього насправді видатного філософа XX-го століття, а й повернула дискусію у напрямку самих підвалин націонал-соціалізму та їхніх освітніх імплікацій. П. Травни, керівник інституту Мартіна Гайдеггера у Вупперталі, в інтерв’ю, даному В. Айленбергеру, слушно вважає, що чернетки філософа однозначно дозволяють зробити такий висновок: «Гайдеггер вважав, ... що не німці виступають проти євреїв, а нацисти, німців як народ він розуміє у цілковито інший спосіб. Треба ще раз наголосити, що Гайдеггер, і про це переконливо свідчать «Чорні зошити», ніколи не був палким прихильником націонал-соціалізму. Він дуже швидко розібрався, що нацисти є протагоністами «махінаторства» (Machenschaft). Він побачив, що конфлікт між євреями і нацистами відбувався під знаком «махінаторства», приписуваного один одному» (Trawny, 2014: 73-74). Можна погодитись, що висловлювання Гайдеггера носили екзистенціально-філософський характер і не передбачали практичних наслідків. Разом з цим Гайдеггер, на думку багатьох дослідників, був і залишається «небезпечним мислителем», бо суб'єктивістська політизація і педагогізація його філософських розвідок використовувалась у тоталітарних виховних практиках (Eilenberger, 2014: 69). У контекстах расової теорії поняття фундаментальної онтології Гайдеггера набували не притаманних їм смислових відтінків. Так, поняття «безрідність» у поєднання з поняттями «не укоріненість» та «безгрунтовність» органічно вписувались до антисемітського дискурсу (Wolin, 2014: 77).

Теоретизація антисемітизму як до, так і після Першої світової війни, була пронизана духом політичної романтики і здійснювалась за критерієм «друг/ворог», а «єврейство» розглядалось як суспільна загроза. Разом з цим нерідко застосовувалась антропологічна аргументація для опису несумісності єврея і німця, бо начебто єврей за своєю психологією нездатний піднестись до високого призначення і покликання німців, не говорячи про всі негативні риси характеру, які приписувались єврейській національній психології. ${ }^{1}$ Цей стереотип мислення попри його примітивність дозволяв досить ефективно маніпулювати суспільною свідомістю, легко приймати і так само легко відміняти рішення навіть на державному рівні. Так, одним з загально відомих казусів націоналістичної освітньої політики Третього рейху була заміна латиниці на сюттерлін

\footnotetext{
${ }^{1}$ Як зазначає В. Клемперер, у Дрезденському університеті у 1933 р. від професорів єврейської національності вимагали дописувати до книжок, виданих німецькою мовою, «переклад з єврейської (Klemperer, 1970: 40), а так званих «кремлівських євреїв Троцького та Літвінова називали Троцький-Бронштейн та Літвінов-Фінкельштейн» (Klemperer, 1970: 98).
} 
- готичний шрифт, розроблений Лео Сюттерліном ще у 20-х роках, коли у Німеччині набувала обертів мода на усе національне. Після приходу націонал-соціалізму до влади у 1933 р. школи і університети у Німеччині директивно мали перейти на новий шрифт як такий, що відповідав німецькому духу. Але вже у 1935 р. цей шрифт було відмінено начебто через те, що його розробника запідозрили у єврейському походженні, хоча той був корінним німцем. Расовий аргумент тут застосовується 3 метою приховання складнощів із загальнонаціональним впровадженням цього шрифту ${ }^{1}$. Націоналістична міфотворчість у даному випадку була змушена поступитись аргументам раціонального вибору як одного із засадничих принципів існування індустріального суспільства.

Але для освітніх і виховних практик мають значення не тільки культурні техніки, а й особливості мовної реальності, у якій відбувається соціалізація молоді. Самостилізація, театралізація, патетика і риторика виступають важливими інструментами ідеологічного впливу на людей з боку націонал-соціалізму, ворогами якого був не тільки більшовизм, а й буржуазна культура і навіть християнська релігія, смисли якої вибірково застосовував для власних потреб націонал-соціалізм². На думку ідеологів Третього рейху, усі ці ворожі впливи перешкоджали поверненню німців до своїх витоків. Під їхнім тиском почалась змінюватись навіть німецька мова через залучення до неї політичного сленгу фашистської диктатури.

\section{Мова Третього рейху та образи людини як інструмент тоталітарного національно-патріотичного виховання}

Гумбольдтіанська концепція мови та їі екзистенціально-антропологічна інтерпретація використовувались новою владою як своєрідна легітимація на послідовне знищення старої культурної традиції освіченої буржуазії. Вже із самого початку в ідеології націонал-соціалізму було закладено дві стратегії щодо мовної політики. 3 одного боку, це стратегія повернення до витоків, до духу і мислення давніх германців, а з іншого - намагання впровадити як нове мислення, так і нову мову у «нордичної людини» індустріального століття. Але навіть нові медійні стратегії не сприяли реалізації цих стратегій, що суперечили одна одній так само, як нацист з вищою освітою з прихованою зневагою ставився до бруталь-

\footnotetext{
${ }^{1}$ У проведених мною наративних інтерв'ю з докт. Гізелою Розендаль, докт. Г. Цезар, поетесою Е. Галленкемпер та докт. В. Бройхером (січень-лютий 1999) усі вони підтвердили версію щодо нездатності більшості представників верхівки Третього рейху оволодіти технікою письма цим шрифтом.

${ }^{2}$ На це звертає увагу В. Клемперер (Klemperer, 1970: 25). .
} 
них і незносних у побуті «товаришів по боротьбі», лексика яких відверто дратувала оточуючих.

Книги «Майн кампф» Гітлера та «Міф 20-го століття» А. Розенберга стали програмними документами світоглядної переорієнтації німців, а також дали поштовх поширенню моди на нові мовні уподобання з екзальтацією та штучним пафосом. Зловживання суперлативами, діаграмами, великими числами та іншими гіперболізаціями не тільки у цих, а й у інших ідеологів Третього рейху, запозичене з американської культури, застосовується для підвищення ефективності політичної пропаганди і мобілізації широких верств населення на реалізацію геополітичного проекту націонал-соціалізму під гаслом «Німеччина понад усе» і намірами перетворити Європу на фортецю (Festung Europa). «Побудова нової Европи», під якою розумілось розширення німецького простору, мала стати перспективним завданням молоді, на яку особливо покладали свої сподівання ідеологи націонал-соціалізму, вбачаючи в ній інструмент для реалізації своїх цілей.

Сама ідея Європи при цьому була змінена у націонал-соціалістичному дусі. Вона визнається породженням нордичного германського духу. Через це перед німцями постає завдання захистити континент від зазіхань британців та французів, але передусім - від більшовиків та усякої іншої азіатчини, або пафосно-метафорично - озброїтись «перед наступом степу на Європу» (vorder Versteppung Europas) ${ }^{1}$. Німцям як носіям германського духу нав'язувалась імперська за своїм змістом думка, що вони повинні рятувати стару Європу як успадковану фактичність (Tatsache Europa), гвалтовно змінюючи їі за сценарієм А. Розенберга. Вже ці, на перший погляд, незначні зміни у семантиці Європи послуговують індикаторами зрушень у політичній і соціальній психології німців, що знайшло свій відбиток у мовних уподобаннях ідеологів націонал-соціалізму, які поширювались також на освітні та виховні практики. Це супроводжувалось посиленням семантики народу і народного. За спостереженнями В. Клемперера, слово «народ» так само часто вживалось у мовленні та на письмі, як сіль у їжі: до усього додавалась щіпка народу: народне свято, народні герої, народна культура, шкідники та тілі народу та ін. (Klemperer, 1970: 41, 293).

Разом з цим треба зазначити, що у мовній політиці націонал-соціалізму бракує креативності і послідовності, хіба що посилаючись на В. Гумбольдта, ідеологи Третього рейху намагались довести абсурдне твердження, що німецька мова не є рідною для асимільованих євреїв, які вже кілька поколінь жили у Німеччині і робили свій внесок до скарб-

\footnotetext{
${ }^{1}$ На зміни у лексиці звертає увагу В. Клемперер (Klemperer, 1970: 199, 201-202).
} 
ниці німецької культури. Як приклад тут можна навести звинувачення Г. Гайне у привласненні німецької мови. На цій підставі було заборонено його вірш «Лорелея» і пісню на його слова, яка до цього вважалась «народною». Ідеологи націонал-соціалізму цілком свідомо у варварський спосіб деформували німецьку літературну мову, яка виступала одним із чинників формування габітусу освіченої буржуазіі. Втрата іiі провідної позиції у німецькій культурі супроводжувалась піднесенням містифікованого колективного образу народу та його основних символічних репрезентацій: ключових фігур Робітника і Солдата, мовою яких є дії, що начебто сприяють піднесенню національного духу. Останній мислиться передусім як дух німецької давнини, який розмовляє на «жаргоні

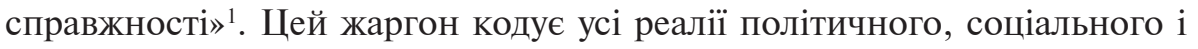
культурного життя за суб’єктивним критерієм справжнє/несправжнє, причому останнє є негативом першого. У мовному плані це здійснюється дуже примітивно - за допомогою заперечної частки «не» (Un-), наприклад: держава/недержава, людина/нелюдина. Тим, хто користувався жаргоном «несправжності» закидали носіння «єврейських окулярів» або звинувачували у прислуговуванні «кремлівським євреям та більшовикам» (Klemperer, 1970: 225, 98).

Цей жаргон, або мова Третього рейху, у своїй словотворчості обмежується штампами ідеології націонал-соціалізму, яка у школах насаджалась учням. В. Клемперер, відомий філолог і включений спостерігач цих змін, зазначає у цьому зв’язку: «Третій рейх створив небагато слів своєї власної мови, навіть можна сказати - жодного. Нацистська мова певною мірою походить ззовні, а усе інше було запозичене у німців догітлерівської доби. Але вона змінює ціннісні акценти у словах, а також частотність їхнього вжитку, перетворює на загальне те, що раніше належало одиничному або маленькій групі, вона конфіскує для партійних потреб те, що раніше належало усім, пропитує своєю отрутою слова і словосполучення, ставить мову на службу своїй жахливій системі, перетворюючи їі на потужну та дієву публічну рекламу» (Klemperer, 1970: 25).

Як приклад тут можна навести вживання слова «праця» у тоталітарних соціокультурних контекстах індустріального суспільства і масової культури. Вона проголошується «найвищою цінністю» німецького народу і виховним орієнтиром не тільки для молоді, а й для дорослого населення, бо «тотальна мобілізація» поширювалась на усіх. У 1933 р. виникають такі організації як Німецький трудовий фронт» (DAF), «Краса праці», «Праця визволяє» та ін. (Kammer, Bartsch, 1992: 46,189). Більш розгорнуту семантику праці представлено у поданих нижче перекла-

\footnotetext{
${ }^{1}$ Особливості цього жаргону аналізуються у праці Адорно «Жаргон справжності», яка розглядалась у попередніх числах цього журналу (Култаєва, 2017: 153-195).
} 
дах спогадів включених спостерігачів описаних процесів. Ставлення до праці і до іï виховного потенціалу тут певною мірою нагадує етику протестантизму. Але у даному випадку праця розглядається не тільки у іiі морально-етичному аспекті, заданому етикою протестантизму, чи у площині індустріалізму як нової економічної реальності, а й також у контексті націоналістично витлумаченої ідеї соціалізму, тим самим підкреслюючи розрив з буржуазним розумінням праці та акцентуючи ії людинотворчий і виховний потенціал, але при цьому латентне нагадуючи про «ворогів» націонал-соціалізму. Сумнозвісне гасло «Праця визволяє» на воротах концентраційного табору розкриває цинізм і злочинність такого роду практик перевиховання, коли праця і ліквідація вживаються як синоніми, заперечуючи людяність у кримінальних закладах «перевиховання» 3 крематоріями для тих, хто «нездатний перевиховуватись». 3 іншого ж боку, у процесі формування робочої, військової, інтелектуальної та політичної еліт режиму на підставі расової селекції людського матеріалу також висувалась патетична вимога відданої праці на рейх i вірного служіння фюреру.

Маніпулятивне застосування семантики праці простежується у гіперболізованому образі людини праці - Робітника та його антиподів. Робітник і Солдат - це ключові фігури рольової реальності ідеології Третього рейху, які за своєю значущістю тут поступаються хіба що фюреру. Але при конкретизації цього образу виявляються проблеми з невизначеністю онтологічного статусу образу Робітника, який вже через свою піднесеність не може бути простим представником робочих професій. Цей образ охоплює людей, які працюють руками (Handarbeiter) і головою (Kopfarbeiter). Можливі також взаємопереходи між Солдатом і Робітником (Arbeiterder Stirnund Faust - працюючі лобом та кулаком) в умовах постійної боротьбі за ствердження німецької нації (Friedemann, 1994: 17-18). Ці два типи уособлюють такі риси особистості як відповідальність, самопримус, самодисципліну, ретельність, а головне - відданість справі. Антиподами Робітника на рівні соціальної реальності виступають нероби і сачки (Arbeitsscheue), яких за указом Гімлера від 26.01.1938, треба перевиховувати, тобто примусово направляти до трудових таборів. Набути статусу нероби чи сачка могла будь-яка людина. Так, кваліфікований працівник, якому пропонували некваліфіковану фізичну працю, у разі повторної відмови автоматично вважався неробою з усіма наслідками занесення до цієї когорти і розглядався як такий, що потребує перевиховання. Це ж саме торкається й визначення інших асоціальних елементів, які загрожували народній спільноті вже самим фактом свого існування. Окрім вже названих нероб і сачків, сюди входили гуляки та скиглії (Friedemann, 1992: 21-22). Ворогами націонал-соціалізму прого- 
лошуються також представники декадентського мистецтва з тавром деградації (entartete Kunst), різного роду збоченці, усі нижчі раси, або недолюдки (Untermenschen). Культ здоров’я, спорту і взагалі - тілесності призводив до засилля спортивної лексики при описах подій на фронтах та у повсякденності (Klemperer, 1970: 284-285) ${ }^{1}$.

Мова Третього рейху, яка застосовувалась в освітніх і виховних практиках державних навчальних закладів, також була не позбавлена політичного сленгу націонал-соціалізму, але вона характеризується посиленою романтичною семантикою. Це знаходить прояв у світоглядній інтерпретації мовної реальності, у селекції лексики за критерієм відповідності німецькому духу. Звідси - вимога повернення до витоків, яка реалізовувалась через застосування архаїзмів як своєрідних маркерів вже згаданого вище «жаргону справжності». Але на практиці усе залежало від культури та освіченості вчителів. Цей момент також розкривається у перекладах, доданих до цієї статті.

Поетика націонал-соціалізму, його піар-акції та риторика в останні роки інтенсивно досліджуються у площині медійної філософії, де відзначаються такі іiі риси, як популістський пафос, вміння підкоряти маси і авторитарно контролювати їхню свідомість (Koschorke, 2016: 16-18). Але перші спроби такого аналізу були зроблені ще до приходу Гітлера до влади. Тут треба передусім згадати Гюнтера Андерса, першого чоловіка Г. Арендт і автора сучасної оригінальної концепції тоталітаризму, аналіз якої буде запропоновано в наступних числах журналу. Біограф, послідовник і друг цього оригінального філософа К.П. Лісман зазначає, що Андерс прочитав «Майн Кампф» ще у 1928 р. і одразу ж, на відміну від багатьох інших поверхових критиків, вважав цю книгу «безсумнівно захоплюючою та інтелігентною попри їі вульгарність», бо «ця людина говорить, що вона думає, і думає, про що говорить» (Liessmann, 2002 : 19).

Спираючись на методологічне розрізнення обмежених (restricted) i вироблених (elaborated) мовних кодів, запропоноване Б. Бернстайном², розглянемо функціональну диференціацію мови Третього рейху, яка у вигляді обмеженого коду деформувала свідомість і життєвий світ пересічної людини, особливо вихідця з німецької глибинки. Така людина ідентифікує себе 3 «народним духом» і непомітно для себе починає застосовувати мовні приписи ідеологів націонал-соціалізму у повсякденному спілку-

\footnotetext{
${ }^{1}$ Перенесення спортивної лексики у політичну і культурну площину, а також візуалізація досягнень цифрами і діаграмами була запозичена німцями у США ще у часи Ваймарської республіки, але маніпулятивна ефективність цього досвіду була використана у повному обсязі лише у часи націонал-соціалізму (Becker, 1993: 12-22).

2 Див.Bernstein B.Class, Codes and Control. Volum 111: Towards a theory of educational transmission. London: Routledge\&Kegan Paul, 2003.
} 
ванні. Так, у розмовах про одруження і буденні справи, за спостереженнями Клемперера, усе частіше лунають слова про арійське чи нордичне походження, про расову чистоту і гігієну, спадок предків (Ahnenerbe) тощо без розуміння їх дійсного значення (Klemperer, 1970: 117).

Шодо виробленого мовного коду ідеології націонал-соціалізму треба зазначити, що у ньому почасти збережено солдатський сленг (особливо у період до приходу Гітлера до влади) та мовні уподобання богемної та напівосвіченої буржуазії, особливо це торкається застосування гіперболізацій на зразок «незчисленні», «дивовижні», «неповторні». Ідеологи націонал-соціалізму приватизували також християнську теологічну лексику з метою надання своїм ідеологемам вигляду нової релігії (спаситель, мучеництво, жертвоприношення, вічна варта, тощо). Клемперер звертає увагу на те, що своїх загиблих охоронців Гітлер називає «своїми апостолами», провіщуючи їм «воскресіння у Третьому рейху» (Klemperer, 1970: $137)^{1}$. Слова «штурмовики», «боротьба», «борці» і похідні від них на зразок «товаришів по боротьбі» також мають подвійну конотацію, вказуючи на учасників Першої світової війни, а разом з ними - також й на тих, хто встановлював і захищав нацистський режим. Абревіатури у Третьому поступались за частотністю мові комуністичних ідеологів, але так само послуговували маркером суспільних інновацій. Так, концентраційні табори позначались абревіатурою KZ, нові організаційні форми проведення вільного часу - KdF (Kraft durch Freude - сила через радість), національно-політичні освітньо-виховні заклади - Napola (die Nationalpolitischen Erziehungsanstalten), BLUBO (Blut und Boden - кров та грунт).

Вироблені коди мови націонал-соціалізму мають подвійну функціональність. 3 одного боку, вони задають норми для внутрішнього спілкування між націонал-соціалістичними елітами, особливо між тими їхніми представниками, які вийшли з прошарку освіченої буржуазії та інтелігенції і домагались літературного визнання. 3 іншого ж боку, ці коди застосовувались для пропаганди ідей націонал-соціалізму. 3 цією метою застосовувалась архаїзація лексики, здебільшого через вживання застарілих форм словотворення, які були покликані повернути молодь до витоків «германського буття», до народного німецького духу. Метафора Ніцше про примхливе «вухо нашого мислення» розкриває один з механізмів формування людини, відданої сумнівним ідеалам націонал-соціалізму. Архаїка входить в це вухо і деформує мислення, освітні та виховні практики, тим самим руйнуючи життя людини. Після Першої світової війни з'являється мода на германські імена, які стають майже нормативною вимогою у Третьому рейху (Зігфрід, Лоенгрін, Брунхільда, Валь-

\footnotetext{
${ }^{1}$ Сам фюрер, на думку Клемперера, позиціонував себе «новим Христом, німецьким зондерспасителем (Sonderheiland), див: (Klemperer, 1970: 142).
} 
трауд, Уте та ін.). Сама мова, намагаючись бути езотерично-вишуканою, перетворюється на штучну і театралізовану з надмірною емоційністю і патетикою. Наведемо деякі приклади, на які звертає увагу Клемперер і які вживаються без перекладу на українську мову як живе нагадування про жахіття Другої світової війни. Це слова «рейх», «фюрер», «хайль» та ін., що не потребують перекладу, бо перетворились на інтернаціоналізми з негативним смисловим навантаженням.

Але їхня семантика потребує уточнення, бо проливає світло на національну ментальність німців та іії зміни, що відбулись під впливом тоталітарної ідеологіі. Ідеологи націонал-соціалізму із самого початку не випадково назвали свій політичний конструкт «рейхом». Клемперер зазначає у цьому зв'язку: «Слово «рейх» означає щось урочисте, передбачає релігійну гідність, яка відсутня в усіх синонімічних виразах. Адже республіка - справа усіх громадян, спільно створений і обов'язковий для усіх лад, це виключно поцейбічна і розумна побудова. Те ж саме можна сказати й про ренесансне слово «держава», яке має виключно поцейбічне політичне значення. Рейх, навпаки, передбачає вихід у більш широку сферу, він поривається до більш високого, трансцендентного. Християнське потойбічне - це царство небесне ${ }^{1}$ (Klemperer, 1970: 142). Таке суто німецьке розуміння державності має глибоке історичне коріння. Продовжуючи свій політико-лінгвістичний аналіз, Клемперер нагадує, що «перша загальна державна форма Німеччини (1806 р.) мала назву «Священний Римський рейх німецької нації». Але слово «священне» тут не є епітетом, вжитим задля краси та посилення ентузіазму, воно акцентує співприсутність трансцендентного, освяченого потойбічними силами» (Klemperer, 1970: 143). Теж саме можна сказати і про привітання «Хайль Гітлер!» та «Німеччина хайль!», тобто небо і доля через цю лексику благословляють націонал-соціалізм на задумані звершення, а дії його функціонерів та активістів відтак санкціонуються вищими силами і через це стають священними, так само як і війна проти світового єврейства.

Мовне трюкацтво Гітлера змінювало опції сприйняття водночас історичних і геополітичних реалій. Після приєднання Австрії і надання їй регіонального статусу (Ostmark замість Österreich) образ Нової Німеччини вже вкарбовується у суспільну свідомість як «Священний германський рейх німецької нації». Ця містифікація широко застосовувалась у національно-патріотичному вихованні молоді і працювала на створення іміджу країни, яка начебто виконує доручення вищих сил і опікується виключно німецькомовним населенням, не маючи жодних загарбницьких намірів. Клемперер підкреслює у цьому зв’язку: «Стабілізуючи Гер-

${ }^{1}$ Царство небесне (Himmelreich) у дослівному перекладі означає «небесний рейх». 
манський рейх, Гітлер використовує полиск старого рейху для своєї нової конструкції» (Klemperer, 1970: 143) ${ }^{1}$. У період самоствердження націонал-соціалізму викладання історії та культури Німеччини було наповнено переважно цим постсекулярним полиском, тим самим готуючи молодь при нагоді пройти випробування на вірність рейху і навіть померти за нього. Парадоксальним чином ця міфологема цементувала німецьке суспільство, створюючи щось на зразок органічної солідарності та готовності до жертовності задля цілого, що є типовим проявом масових психозів у тоталітарних соціумах.

Мовним уподобанням ідеологів націонал-соціалізму відповідали образи людини, які були домінантними в ідеології Третього рейху. Вони стають своєрідними гіпертипізаціями, які популяризуються і політизуються як на теоретичному, так і на практичному рівнях (Zichy, 2017: 109). Передусім це герой, головним досягненням якого є «героїчна смерть». Цей образ, закріплений у німецькому фольклорі, ідеологи націоналсоціалізму намагались приватизувати і широко застосовували його у виховних практиках. Привілеєм героїчної смерті наділяються тільки прибічники націонал-соціалізму, а ворогам відмовляють у такій можливості. Герой посилює свій образ ідентифікацією з образом тварини-хижака, здебільшого лева або вовка. Наскільки закріпленими у свідомості індивідів залишаються ці образи свідчить той факт, що у роки війни деякі важко поранені солдати і офіцери вже у мирному житті продовжують називати себе на зразок німецьких лицарів тваринними символами. Так, під час роботи лекторкою на західнонімецьких освітніх круїзах (Bildungsreisen) по Дніпру у 1984-1988 рр. мені довелось брати наративні інтерв’ю у колишніх «героїв» рейху: «Черкаського лева», «Дніпровського сокола», «Степового вовка» тощо. Старі люди, колишні німецькі загарбники, здійснюючи свою позірну ідентифікацію на основі цих образів, намагались відтворити своє сумнівне «героїчне» минуле навіть після його «опрацювання» і денацифікації. Тваринні образи корелюють із запозиченим у Ніцше образом надлюдини (Übermensch) як «білявої бестії, тобто лева, яка в ідеології Третього рейху виконувала функцію орієнтира життєтворчості німців та їхнього виховного ідеалу. Тваринні образи мали також сигнальне значення, мобілізуючи молодь на боротьбу з нижчими расами, інвалідами, психічно хворими тощо, бо ті носили тавро недолюдини (Untermensch).

${ }^{1}$ Деякі дослідники вважають, що ідея перетворення міфологеми Третього рейху на політичну ідеологему належала Т.Манну, а вже потім, після 1919 р. воно стало паролем «консервативної революції», а поштовх такій інтерпретації надали праці К. Лампрехта і Д. Мережковського (Martynkewicz, 2011: 237). 
Спорт, здоровий спосіб життя, робота над загартуванням і красою тіла, а згодом і військова підготовка, як вже зазначалось вище, займаючи одне з центральних місць у філософії виховання Третього рейху, також застосовувались як критерії, за якими здійснювалась селекція людського матеріалу. Віднесення людини з обмеженими можливостями до нижчої когорти автоматично означало позбавлення іiі гідності, будьяких прав і зрештою означало легітимацію на їі знищення. 3 цим образом пов’язано поняття «знеціненого життя» (unwertes Leben), яке застосовувалось для виправдання злочинів проти людяності.

Мілітаризація нормативно-позитивного образу людини у Третьому рейху знайшла візуалізацію у вже згаданих вище образах Солдата і Робітника, які уособлювали готовність служити Німеччині під керівництвом фюрера, а також виступали знаковими фігурами процесу індустріалізації Німеччини. Технічна лексика як специфічна данина такій фрагментарній модернізації також присутня у політичному сленгу націонал-соціалізму, що певною мірою суперечило завданню реанімації германського духу. Але «система» і «організація»- улюблені концепти фашистських функціонерів - визначають межі уповноважень інструментального розуму та ірраціональної міфотворчості ідеології націоналсоціалізму. Тут на особливу увагу заслуговує запозичене з електротехніки слово Gleichschaltung, яке у перекладі означає одночасне підключення фаз. Після приходу Гітлера до влади таке колективне підключення, точніше самопідключення (Selbst-gleichschaltung), освітніх закладів було ідеологічною вимогою їхнього начебто добровільного підпорядкування тоталітарній державі, отже, із самого початку це слово містило у собі також семантику знищення або усунення не підключених до ідеологічної мережі ідейних та расових ворогів серед професорсько-викладацького складу (Reimann, 1986: 41, 47-48).

Ключову роль у цих процесах відігравав містифікований і функціонально диверсифікований образ фюрера. На відміну від комуністичних вождів, суспільне призначення фюрера та його функції розкриваються занадто абстрактно і до того ж - в ірраціональній площині. Фюрер як носій народної волі не є функціонером або виразником чиїхось класових або групових інтересів. Він, точніше його воля, радше виступає медіумом для прояву народної волі. Досліджуючи інституційні зміни німецького університету в часи гітлерівського режиму, Т. Ельвайн звертає увагу, що уповноваження фюрера, навіть у Конституційному праві Третього рейха, виписані досить невизначено, до того ж - з елементами містицизму. У фактологічному додатку Ельвайн наводить перелік функціональних обов'язків фюрера, зроблений одним з провідних конституційних юристів держави У.К. Губером: «Фюрер формує у собі справжню 
волю народу, яку треба відрізняти від суб'єктивних переконань відповідних живих членів даного народу. Він є відданим об’єктивній історичній єдності і цілісності народу. Через це він може від імені справжньої волі народу, якому служить, виступати проти суб’єктивних думок і переконань окремих членів народу, якщо ті будуть відвертатись від об'єктивного покликання народу. Тоді він відстоюватиме об'єктивну ідею нації проти суб'єктивної сваволі хибно скерованого народного настрою. У часи внутрішньої скрути фюрер може повертати до самого себе народ, який забув про своє політичне призначення або зрадив йому» (Ellwein, 1992: 306-307). Отже, фюрер в ідеології націонал-соціалізму - це не просто керманич, а провидець, виконавець історичної місії самоствердження німецької нації як такої, що перевершує усі інші.

Ідеологія німецького фашизму, насичена такими ідеологемами, є комунікативно закритою і демонструє нездатність до критичної саморефлексії. Через це вона дуже легко відмітає будь-які закиди у свій бік. На цей момент одним з перших звернув увагу Б. Брехт: «На закид щодо грубості фашизм відповідає фанатичним схваленням грубості. Якщо його звинувачують у фанатизмі, він відповідає возвеличенням фанатизму. На звинувачення в руйнації розуму він реагує винесенням смертного вироку розуму» (Brecht, 1980: 475). Безперечно не усі німці мислили такими ідеологічними штампами і висловлювали свої думки на «жаргоні справжності». Але цей жаргон як мова «нової народною інтелігенції» на відміну від «старої пихатої і зарозумілої» - був підтриманий німецьким націоналістично настроєним студентством та «антибуржуазними» професорами, які знаходились у полоні ілюзій політичної романтики або 3 кар'єрних міркувань демонстрували лояльність тоталітарному режиму 3 його негативним ставленням до проявів свободи думки та аполітичності.

\section{Підключення німецьких університетів як трагедія німецької національної системи освіти}

Структурні зміни в системі освіти Третього рейху відбувались в комплексі з інституційними змінами, необхідними для переходу зі стану «руху» до стану так званої «стабілізації через організацію». Підпорядкування тоталітарній державі німецьких університетів, у яких високо шанувався принцип автономіі, був шоком для більшості представників аполітичних академічних спільнот, які не чинили опір цьому процесу. Але через романтичне сп'яніння від національної ідеї та національних німецьких цінностей чимало німецьких професорів (М. Гайдеггер, К. Шмітт, Г. Фрайер, Е. Ротхакер та ін.) підтримали політизацію німецьких університетів. Це дає підстави говорити про самопідключення ні- 
мецьких університетів до ірраціонального проекту конституювання нової німецької дійсності. Але організація і державне управління освітою і наукою вимагають елімінації ірраціонального, бо управління потребує прийняття виважених і відповідальних рішень. Так звані «патріотичні управлінці» 3 притаманним їм волюнтаризмом виявились нездатними до такої діяльності, не говорячи вже про модернізацію університетів, бо лідер-фюрер принципово відрізняється від лідера-менеджера способом мислення і прийняття рішень. Дещо перефразуючи М. Вебера, можна сказати, що у першому випадку домінує етика переконань і воля політика, а в другому - етика відповідальності і логіка справи. Через це авантюра з одночасним підключенням німецьких університетів до системи націонал-соціалістичного живлення була приречена на невдачу.

Розглянемо це на прикладі казусу Гайдеггера, який з ентузіазмом сприйняв процедуру підключення, вбачаючи в ній можливість модернізації застарілих німецьких університетів і їх наближення до потреб німецького суспільства. Його промова на урочистостях з приводу вступу на посаду ректора Фрайбурзького університету (1933 р.) має назву «Самоствердження німецького університету», яка говорить сама про себе. Гайдеггерівське розуміння дійсності і перспектив німецького університету є домодерним, а лінгвістичні характеристики його промови визначаються риторикою, стилізованою під архаїку і навіть під середньовічну схоластику з домінуванням загальних концептів на зразок студентства, учнівства, вчительства. Академічна спільнота у цій промові набуває статусу «почту» (Gefolge). «Пробудження і зміцнення» цієї спільноти можливе лише із середини «істинного і спільного укорінення у сутності німецького університету» (Heidegger, 2014: 4). Сама ця сутність, проникнення до якої Гайдеггер вважає своїм «духовним дорученням», потребує прояснення, адже вона не може виступати навіть формальною метою модернізації німецького університету. На його думку, «ця «сутність прояснюється, показує свій ранг та силу завжди й передусім тоді, коли фюрери також стають тими, кого веде невблаганність того духовного доручення, яке спонукає долю німецького народу стати відображенням своєї історії» (Heidegger, 2014: 4). За логікою розуміння механізмів самопідключення як «духовного доручення», містифікована сутнісна воля дає інструментарій для реалізації таких амбіцій, віддалених від суспільного життя академічної спільноти. Але перетворення цієї спільноти на «почет» обраних, тобто «добровільно підключених», потребує самообмеження задля створення вертикальної субординації на основі принципу фюрерства, тобто встановлення ієрархії лідерів, у яких воля і світогляд замінювали конкретні управлінські знання і досвід. Ця ієрархія вибудовувалась за ідеологічними настановами націонал-соціалізму, але Гай- 
деггер надає їй романтичного забарвлення, відсутнього у конструктах технократичного інструментального розуму. У цій ієрархії призначений згори ректор є фюрером університету, ним безпосередньо керує фюрер держави, функції якого наведені вище і не мають нічого спільного з держуправлінням. Фюрер університетського масштабу в свою чергу призначає фюрерів факультетів, а ті - фюрерів студентських груп, створюючи видимість позірного самоуправління і залучення молодих лідерів, хоча частина заходів та акцій з боку студентських активістів дійсно була успішною, наприклад протести проти звільнення деяких професорів, які не поділяли поглядів провідних ідеологів націонал-соціалізму, але були знавцями своє справи і користувались повагою молоді. Варто зазначити, що у студентському середовищі ще зберігався досвід корпоративної організації та демократичні процедури Ваймарської республіки, але при цьому мали вже розглянуте вище специфічне розуміння демократії. Як зазначає В. Абендрот, студенти були захоплені політичною романтикою Шмітта і «окрилені вітальним активізмом, який спонукав їх побудувати щось нове власними руками» (Abendroth, 1986: 29-30).

Структурна зміна організації університету та академічного життя, впроваджена ідеологами націонал-соціалізму, обмежувала академічну свободу і руйнувала життєві плани студентів, які мріяли про кар'єру в науці, освіті, медицині, юриспруденції чи про посаду держслужбовця. Такі меркантильні і прагматичні мрії у середовищі переконаних прихильників режиму були предметом громадського осуду як буржуазні чи філістерські, не гідні героїчного покликання німецького студента. Гайдеггер рішуче виступає проти таких мрій. Як ректор він робить усе, щоб ті ніколи не здійснились. Перед усім відкидається спеціалізація навчання на усіх факультетах, бо навчатись відтепер треба «цілому», тобто тотальності духу. «Часто оспівану «академічну свободу», - повчає Гайдеггер-ректор, який суперечить Гайдеггеру-філософу, - треба вигнати геть з німецьких університетів, бо ця свобода була несправжньою через їі негативність. Здебільшого вона означала безтурботність, неясні наміри і схильності, безвідповідальність як у діях та і у бездіяльності (Heidegger, 2014: 9). Поняття свободи німецьких студентів, на його думку, тільки при націонал-соціалізмі повертається до своєї істини. На цій основі, за Гайдеггером, мають утворюватись «зв’язки між народом і долею держави» і стверджуватись етика служіння, необхідна для виховання і самовиховання німецького студентства. Ця етика поширюється на усі сфери екзистенційно значущої діяльності студентства. Це трудова і військова повинності, а також служіння науці (Heidegger, 2014: 10). Академічна спільнота, за логікою ідеологів націонал-соціалізму та їхніх прибічників, повинна була «перевиховуватись і самоперевиховуватись», орієнту- 
ючись на вже згадані вище образи Солдата та Робітника, тобто служити Німеччині і захищати іiі, бути готовою до самопожертви. Гайдеггер покладає на німецький університет високу, але практично нездійсненну місію: «Бути фюрером і охоронцем долі німецького народу», бо він із середини науки і через неї здійснює виховання і дисциплінує народ» (Heidegger, 2014: 10).

Вимога фанатичного патріотизму у суспільних констеляціях тоталітарного суспільства підкріплюється не рівнем розвитку моральної свідомості, а волею та силою характеру. Не дивно, що їх формування займає одне з першорядних місць у стратегіях і практиках виховання нової німецької людини. Така зміна акцентів передбачала зсуви у владному балансі академічної спільноти у бік студентів, які контролювали викладачів, оцінювали їхню лояльність режиму, вимагали посилення національної складової в науці, хоча беззаперечно виконували накази своїх фюрерів, яких дозволялось замінювати, якщо ті не відповідали директивним вимогам владних інституцій і вищого керівництва. Під впливом політичної пропаганди та настроїв в дусі політичної романтики деякі професори вже не відчували себе вихователями і наставниками студентів, а прислуговували їм і покірливо виконували вимоги «німецького студентства», вбачаючи у ньому медіум влади. В свою чергу у досить значної частини студентів формуються і закріплюються стереотипи поведінки вічних революціонерів, які жадають «справжніх героїчних вчинків» на війні зі «старим світом» та шкідниками та тілі германського народу.

Корпоративність студентських організацій, розширення функціонального потенціалу студентського самоуправління і практик самопомочі (Selbsthilfe) перетворювались на інструменти тотального контролю за академічною спільнотою, яка примусово поверталась до «народу» і «справжньої народної культури» (wirkliche Volkskultur) та до «органічної істини». Отже, свобода науки, конституційно закріплена у Ваймарській республіці, була фактично скасована через самопідключення німецьких університетів до гітлерівського режиму. Окремі професори могли добровільно відмикати себе від блоку живлення, приєднаного до режиму, інших звільняли за нелояльність до влади або за критику офіційної ідеології, але Університет як один з форпостів режиму завжди залишався підключеним до самого кінця Третього рейху. Адже вже згадана вище етика служіння у науці, так само, як і в інших сферах, передбачала підпорядкування іiі «народному духу», а «засадничою ланкою народного культурного порядку» проголошувався оновлений університет, точніше нова університетська дійсність, що знаходилась під знаком націонал-соціалізму.

Декларативно проголошене оновлення німецької вищої освіти полягало у їі «тотальній мобілізації» задля зміцнення німецької держави. 
Самоствердження університету також передбачало його «очищення», під яким малося на увазі звільнення єврейських професорів, відмову від професорського снобізму і ліберального розуміння науки, бо наукове виробництво ставало частиною ідеологічно контрольованої «культурної роботи». Якщо в СРСР усе духовне виробництво, разом з наукою, було підпорядковане принципу партійності, то націонал-соціалізм виходив з ідеї расової вищості німців. За цією логікою, авангардом науки може бути тільки очолювана арійськими професорами німецька наука на тій підставі, що вона є породженням німецького духу. Як у першому, так і у другому випадку заперечується загальнолюдське призначення науки служіння істині. Ідеологічна узурпація науки руйнує іiї із середини, висуваючи ідеологічні вимоги до змісту та організації наукових досліджень.

Усе це розбешує молодих науковців, продукує ілюзії щодо можливості паранауки на основі езотерики. У тенета гіпертрофованої національної свідомості потрапляли не тільки студенти та гуманітарії, але також й авторитетні представники природничих наук. Як приклад тут можна навести апологію «німецької фізики» лауреатом Нобелівської премії Філіпом Ленардом. На його думку, це «фізика людини з нордичним складом характеру, це фізика засновників дійсності, шукачів істини, фізика тих, хто обгрунтував дослідження природи», а на закид уявних опонентів, що наука $є$ наднаціональною, а її досягнення належать усьому людству, зазначається, що такі висловлювання є хибними: «Насправді наука, як і усе, що роблять люди, обумовлюється расою і кров’ю» (цит. за: Ellwein, 1992: 303). Відповідно до вимог расової чистоти мав відбуватись також й добір студентів ${ }^{1}$.

Отже, умови доступу до вищої освіти формувались на основі расового принципу. Здібності, обдарованість і просто професійна придатність тут не брались до уваги. Існував також обмежений доступ жінок до вищої освіти і додаткові складнощі, які описує Г. Цезар у поданих нижче мемуарах. Щоб стати студентом німецького університету у часи Третього рейху, треба було незалежно від громадянства надати довідку про німецьке походження і знання німецької мови, а також продемонструвати відданість ідеям націонал-соціалізму. У промові Геббельса від 30.05. 1933 р. на акції по «спалюванню «ненімецької писанини» (Verbrennung undeutschen Schrifttums) була зроблена заява про «завершення доби єврейського інтелектуалізму» і здійснення «революції знизу». У цій промові обгрунтовується історична місія студентів як носіїв, поборників і захисників революційної ідеї «справжньої держави» та визнається

\footnotetext{
${ }^{1}$ Аналогом концептів «підключення» $\mathrm{i}$ «самопідключення» на рівні індивіда став поширений у побуті неологізм «онордичення» (Vernordung), тобто доведення нордичного походження.
} 
їхнє право скидати і знищувати фальшивих авторитетів. «Революціонер, - повчає Геббельс, - повинен уміти все. Він мусить бути великим як у знищенні хибних цінностей, так і у створенні справжніх. Якщо ви, студенти, перебираєте на себе право кидати у полум'я духовне сміття, ви повинні також покласти на себе обов'язок звільнити шлях справжньому німецькому духу, прибравши з дороги увесь непотріб. Дух формується у житті і в аудиторіях, адже прийдешня німецька людина буде не тільки книжною, а й також людиною характеру, ми хочемо виховати вас саме такими. Вже з молоду ви повинні мати мужність дивитись у безжалісні очі життя, навчитись не боятись жахливості смерті, щоб знову отримати благоговіння перед смертю - ось це є завданням для молодої генерації» (цит. за: Ellwein, 1992: 301).

Містифікується навіть попіл від спалювання книжок, бо з нього начебто мав повстати «фенікс нового духу». Цій акції передував «Просвітницький похід проти ненімецького духу» (12.04-10.05 1933 р.) по великих містах Німеччини, ініційований студентськими активістами. Вимоги студентів були сформульовані у 12-ти войовничих антисемітських тезах. Вимоги, що містились у них, зрештою повторювали ідеологеми націонал-соціалізму, насамперед посилення дисципліни і політичного виховання студентства, і готували атмосферу до самопідключення німецьких університетів. Виступи проти брехні, заклики до перетворення «німецької вищої школи на місце битви» від імені і в ім'я німецького народу посилювались примітивними антисемітськими сентенціями, мабуть, для легітимації відлучення євреїв від освіти і науки: «Єврей може мислити лише по-єврейськи. Якщо він пише по-німецьки, він бреше. Німець, який пише по-німецьки, але думає не по-німецьки, є зрадником. Студент, який розмовляє і пише не по-німецьки, окрім усього іншого є пустоголовим і зраджує своєму завданню (цит. за: Leske, 1990: 298). Ці вимоги студентів були наслідком світоглядного виховання на основі расової теорії та хибних уявлень про альтернативну «національну науку» як синтез усіх наук на основі германського духу.

Як зазначається у дослідженнях, присвячених історії націонал-соціалізму, Гітлера мало цікавила політика в галузі науки та освіти (Grüttneer, 2009: 32). Реорганізація освітніх інституцій у дусі наведених вище вимог нібито покладалась на лояльних режиму професорів та студентів. Але проводилась вона не на власний розсуд, а суворо дотримуючись ідеологічних приписів. Рейхміністр з науки, виховання і народної світи Руст метою цієї реформи проголошує «синтез вільного дослідження і національно-німецького світогляду», зазначаючи у цьому зв'язку: «Те, що на цей момент може зробити держава, вона вже робить зараз і буде робити це й у подальшому. Вона реорганізує викладацький склад вищої школи за волею 
нації. ... Німецьку молодь вже більш не будуть вести за собою професори з чужої раси (цит. за: Ellwein, 1992: 301). Філософія навчального плану у німецьких університетах також визначалась ідеологічними настановами. Центральне місце в ньому займали народознавство, історія давніх германців, воєнна наука, расова гігієна та євгеніка (Grüttneer, 2009: 45). Цей ідеологічний комплекс доповнювався фаховими дисциплінами, щоправда, в урізаному вигляді. В університетах відчувався гострий дефіцит професорів через звільнення фахівців з расових або ідеологічних мотивів. Кадрові чистки торкались не тільки університетів, а й бібліотек і музеїв. Безлад і напруження в університетах не сприяли позитивним змінам. Після встановлення гітлерівського режиму, як вже зазначалось вище, різко знижується престиж вищої освіти через безробіття випускників університетів. Але переважну більшість студентів після 1933 р. і до самого падіння Третього рейху, за незначними винятками, вже не цікавило навчання та академічна кар'єра, бо їх самоствердження відбувалось за стінами університетів. На початку війни багато з них мріяли про героїчну смерть на фронті як реабілітацію за поразку німців у Першій світовій війні.

Героїзація студентів, які відстоювали ідеї націонал-соціалізму, була одним із заходів, спрямованих на подолання спротиву з боку «ворогів» режиму. Їхній героїзм виявлявся у непримиренній боротьбі з усіма та усім, що стояло на перешкоді самоствердженню німецького духу не тільки у Німеччині, а й в усій Европі. В ранг героїчної фігури, яка мала б бути прикладом для усіх студентів, було піднесено колишнього фрайбурзького студента Ф.Л. Шлагетера, який добровольцем пішов на фронт, але загинув не на війні, а був заарештований під час спроби терористичної акції у Дюссельдорфі і за вироком суду розстріляний у 1923 р. У Третьому рейху Шлагетер перетворився на культового героя як «перший націонал-соціалістичний Солдат», образ якого активно застосовувався у нацистській пропаганді навіть ще до того, як його наділив цим статусом Гітлер у «Майн кампф» (Farias, 1997: 143, 148-149). Страта колишнього студента оспівувалась ідеологами націонал-соціалізму в епічному стилі як смерть «за німецький народ і рейх», що обірвала реалізацію його подальших потенційних героїчних вчинків у Німеччині. Гайдеггер підхоплює не тільки цю сюжетну лінію, намічену Гітлером, а й почасти імітує його стиль. У своїй промові на честь 10-річчя з дня смерті Шлагетера він закликає студентів наслідувати «тверду волю та чисте серце» цього героя, який насправді був терористом. «Фрайбурзький студент,- закликає він, - нехай сила рідних гір цього героя увіллється у твою волю! Фрайбурзький студент! нехай сила осіннього сонця на долинах Батьківщини цього героя осяє твоє серце! Збережи і перше, і друге у 
собі, неси неподільно твердість волі і ясність серця до німецьких університетів і своїх товаришів» (цит. за: Farias, 1997: 147).

Філософсько-освітня публіцистика Гайдеггера не збігається цілком з його філософськими розробками у проблемному полі людського буття, хоча, безумовно, важко відділити філософа-теоретика від філософа-вихователя з уповноваженнями функціонера, тим більш, що навіть на початку націонал-соціалістичного руху не було великого попиту на поради від теоретичного розуму. Але ректорський період в біографії Гайдеггера свідчить, що в стратегії підключення університетів до ідеології націоналсоціалізму починають відігравати все більшу роль світоглядні філософії (Weltanschaungs philosophien), щоправда у націоналістично спотвореній формі. Розглянемо більш детальніше цю тенденцію.

\section{Ідеологізація філософії у Третьому рейху та її освітні імплікації}

Негативне ставлення до філософії, яке домінувало в середовищі активістів націонал-соціалістичного руху до кінця 20-рр., дещо змінилося після приходу їх до влади. Перефразуючи назву відомої праці Ніцше ${ }^{1}$, можна сказати, що ідеологи Третього рейху, особливо ті з них, які мали вищу освіту і навіть науковий ступень (Геббельс, Боймлер, Астель, Гюнтер, Розенберг та ін.) своєрідно вирішують питання про користь і шкідливість філософії для націонал-соціалістичного життя. Від філософії очікували не верифікації настанов офіційної ідеології і надання суспільству нової орієнтації, а підтвердження «органічної істинності» іï світоглядних засад, щоб повернути філософію на те місце, яке вона займала у Середньовіччі, перетворившись на служницю політичної теології Третього рейху.

На підставі того, яка філософія домінує у суспільстві, багато чого можна розповісти про його стан і перспективи. Зневажливе ставлення до філософії або їі відсутність вказують на духовну деградацію соціуму. Догматизація філософії на зразок ідеологізованого марксизму є індикатором стагнації суспільства, яке свято вірить в те, що показує йому його філософський навігатор. Націонал-соціалізм не потребує такого дороговказу, бо його веде за собою і оберігає германський дух, горизонт постійно розсуває воля, а хронотоп складається з необмеженого простору і вічності, включно з потойбіччям. Отже, керуючись психологією свого світогляду, німецький фашизм обирає ірраціональну філософію, яка відповідає його схильності до авантюризму, театралізації, заграванню $з$ долею і темними силами. Філософія тут не призначається згори, як у напівфеодальному тоталітаризмі радянського зразка, а підключається

\footnotetext{
${ }^{1}$ Мається на увазі праця Ніцше «Про користь і шкідливість історії для життя», яка також вплинула на формування ідеології націонал-соціалізму.
} 
до режиму, який змушений постійно імпровізувати, не втрачаючи при цьому артистизму і стилю власних саморепрезентацій в образі розбещеної надлюдини. Підключеними до ідеології націонал-соціалізму стали такі модні течії того часу, як екзистенціалізм гайдеггерівського зразка, німецька філософська антропологія і філософія культури, а також сформовані на їхній основі філософія освіти і виховання. При цьому структура і проблемне поле філософських теорій, які існували в рамках цих течій, зазнали значних спрощень, бо були втиснуті в рамки тоталітарної ідеології і підпорядковувались логіці «підключення». Головне місце в цій структурі займали теоретичні засади «нового» світогляду на основі нордично-арійского міфу (А. Розенберг). У його розбудову зробили значний внесок метафізика Все-життя (All-Leben) та народно-політична антропологія (Е. Крік), психологія рас (Г.Ф. К. Гюнтер), а також політична педагогіка (А. Боймлер), які замінили традиційні тематичні розділи філософської науки (Leske, 1990: 111). Тим самим було розірвано зв’язок з європейською філософською традицією, передусім з їі гуманістичним спрямуванням, а також певною мірою з німецьким ідеалізмом. Відкриття останнього як ідейно-теоретичного посилення ідеологем Третього рейху відбулось пізніше, у часи війни і здійснювалось вибірково, перевага тут віддавалась гегелівській філософії держави і філософії істоpiï. Але вони виконували радше психотерапевтичну функцію упродовж останніх років гітлерівського режиму, який займався самонавіюванням щодо своєї високої місії та позірної незламності.

Традиційно у Німеччині до досліджень у галузі медицини і мистецтва входила філософсько-антропологічна складова. Для лікарів тотальний світогляд націонал-соціалізму, доповнений сентенціями біологізаторської філософської антропології та расової теорії, був легітимацією на проведення експериментів над людьми в концтаборах і лікарнях, керуючись настановами щодо «знеціненого життя», яке підлягало утилізації. Медична етика, що сформувалась на основі ідеології націонал-соціалізму і набула філософсько-антропологічного посилення, була етикою подвійних стандартів. Гуманізм, милосердя, співчуття вимагались від лікаря при лікуванні представників нордичної раси, усі інші розглядались як «біологічний матеріал» для медичних дослідів ${ }^{1}$. Злочини, які

\footnotetext{
${ }^{1}$ Безперечно не усі німецькі лікарі на окупованих територіях діяли за такою подвійною мораллю. Існує багато прикладів емпатії і гуманізму з їхнього боку. Так, під час окупації Харкова молодий хірург Г. Галленкемпер вилікував поранення голови підлітка О.Кропівного, мого чоловіка, яке він, вихований у католицькій родині, одержав під час рятування від пожежі харківської синагоги. Цей факт зафіксовано у щоденнику О. Кропивного та підтверджено у моїх наративних інтерв’ю з докт. Галленкемпером (м. Ален, липень-серпень 1997-98 рр.), існують також свідки цих подій.
} 
чинили медики у концтаборах, багато у чому пояснюються такою подвійною мораллю. Вона виправдовується у ніцшеанстві та його біологізаторських трансформаціях як успішна стратегія виживання і реалізації волі до влади. Засвоєння настанов подвійної моралі націонал-соціалізм відносить до першочергових завдань виховання німецької молоді, особливо у період Другої світової війни.

На підставі аналізу «Таємних промов Гімлера у 1933-1945 рр.» П. Слотердайк розкриває структурні і семантичні особливості такої роздвоєної моралі, які вказують на обізнаність Гімлера у проблематиці культурної і соціальної антропології, а також психології. Слотердайк фіксує цей момент, підкреслюючи, що складається враження нібито Гімлер «вивчив усі підручники з культурної антропології, розвинувши інтуїцію, за якою у середині гострих конфліктів усе залежить від здатності комбінувати високо натягнуту планку внутрішньої етики (Binnenethik) бойової спільноти, скріпленої присягою, з найбрутальнішою розгнузданістю ззовні. Земля, полита кров’ю, змушує від своїх акторів чіткого відокремлення ендо-етики (Endo-Ethik) від екзо-етики (Exо-Ethik]. Звідси виникає сурова заборона на емпатію щодо жертв «необхідних» придушень, навіть щодо дітей і жінок, не говорячи вже про євреїв» (Sloterdijk, 2014: 186).

Окрім зазначених полюсів усередині такої етики як основи морально-етичного виховання німців, ця етика, як «справжня» і до того ж цілераціональна, протиставляється іншій тоталітарній етиці - комуністичній у її радянській версії з наглядачами дотримання комуністичних норм, цінностей і настанов: армією політпрацівників, комісарів, вихователів різного рівня. Це етика рабської праці та військових доіндустріальної доби. В освітньому і виховному плані ідеологи націонал-соціалізму вважають їх «брутальними недоучками», які постійно потребують зовнішнього контролю, в той час, як німецькі культурні і вишколені бійці виключно керуються начебто голосом свого сумлінням (Sloterdijk, 2014: 186). Індустріальна за своїм змістом ідея автоматизації духовного виробництва - наука, освіта і виховання тут не є винятками - сприяла поширенню ілюзії, що всі культурно-освітні процеси відбуваються у площині самодіяльності. Через це німецькій тоталітаризм надавав особистості значно більший люфт фрагментарної свободи, ніж радянський, хоча також суворо доглядав за дотриманням націонал-соціалістичної етики.

Посиленню і ушляхетненню цієї етики смерті і геноциду у різні періоди історії націонал-соціалізму сприяла нацистська узурпація мистецтва і формування відповідної культури смаків з домінантою націоналістичного монументалізму та сільськими ідиліями у вишиванках зі співами і читанням поезій на відповідних регіональних діалектах, а також перебільшене акцентування ідеологічної значущості декоративного 
мистецтва як носія, охоронця та медіуму «народних смислів», начебто придушених агресивною та космополітичною урбаністичною культурою. Разом з цим нові медійні можливості (кіно і радіо) також «підключались» до пропагандистської машини рейху.

Координація цих впливів з боку ідеології націонал-соціалізму була контингентною. Деякі успіхи тут досягались лише через те, що за інерцією збережені смисли гуманістичної традиції актуалізувались у так званій «ендо-етиці». Але кристалізація світоглядних настанов націонал-соціалізму потребувала більш чіткої теоретичної рефлексії, отже, - нової філософії. У Третьому рейху особливо посилився запит на філософію під час Другої світової війни, коли стала суспільно відчутною потреба в «утішанні філософією». Проблемне поле такої «нової» філософії, яка б відповідала запитам ідеологів націонал-соціалізму з їхньою неприборканою волею до влади та вірою в автоматизм самодіяльності, радше нагадує структуру езотеричних вчень з аксіомами віри. Останні окреслювались і задавались у промовах верхівки рейху на чолі з Гітлером. Бажаній філософії тут відводилась функція послужливого постачальника аргументації до легітимації дивакуватих і навіть варварських культурних та політичних інновацій, а також роль своєрідного адвоката диявола, з-під пера якого виходили б філософські апології кримінальних політичних рішень. До того ж така філософія мала б прикрашати фасад підключених освітніх закладів, тим самим сприяючи «оновленню німецького університету», перетвореного на поле ідеологічних битв.

Про все це легко сказати, але важко здійснити, бо філософська еліта Німеччини була вилучена за расовими та іншими ознаками з кола комунікативної спільноти. До того ж ідеологи націонал-соціалізму мали не тільки нав'язувати масам свої сумнівні міфологеми, а й були змушені вести світоглядну боротьбу з британським емпіризмом, французьким просвітництвом та релігійними напрямами сучасної філософії, в тому числі й німецькими. Найскладнішим серед таких завдань була боротьба з іншою версією тоталітаризму - з «більшовистським марксизмом», який також намагався привласнити ідею соціалізму, звертаючись до іiі «наукової інтерпретації, щоправда, з дуже сумнівним критерієм науковості. Націоналістична ж версія соціалізму, навпаки, спиралась на ірраціональні аргументи, віддаючи перевагу ненауковому «живому» світогляду. Так, Геббельс одним з досягнень ідеологічних зусиль націонал-соціалізму вважає «спрощення мислення німецького народу і повернення його до його примітивної праформи» (Цит за: Leske, 1990: 94). Це начебто мало наділяти просту людину неабиякою інтуїцією. Відтак, залучення експертів при розгляді будь-яких проблем виявлялося зайвим, що також негативно вплинуло на світоглядне ви- 
ховання молоді. Теза про перетворення невігластва на передумову проникнення у глибину речей у даному випадку виводилась безпосередньо з «тотальності світогляду» (Totalität der Weltanschauung). Ідеологія націонал-соціалізму, зазначає Геббельс, ніколи не намагалась обгрунтовувати світогляд науково, бо природа виходить за межі науки і формує своє власне життя» (цит за: Leske, 1990: 95). Звідси - інтерес до паранормальних явищ та екстрасенсорних здібностей людини. Такий світогляд приводить у дію жахливу діалектику просвітництва, яка починається із затьмарення розуму і завершується злочинами проти людства (Horkheimer, 1987: 35).

Тоталітарні суспільства, незалежно від їхніх модифікацій і саморозуміння, завжди мали і матимуть клопіт з пересічною людиною, яка з різних причин вислизає з-під тенет «тотальної мобілізації» та диктату «сутнісної волі» держави. Формування нової людини, яка б витіснила, а то й ліквідувала «стару», стає нав'язливою ідеєю ідеологів тоталітарних суспільств. Виконавцями свого задуму вони проголошують вчителів, яким дається «бойове завдання» створення «нового німця», надлюдини, щоб перемогти своїх ворогів і конкурентів, передусім більшовиків, які також бились над створенням нової людини за начерками Маркса, щоправда не занурюючись глибоко у міфи про походження, а лише констатуючи свою класову приналежність. Амбіції ідеологів націонал-соціалізму йшли більш далеко, бо вони намагались встановити новий німецький світоустрій як простір самореалізації німецької надлюдини (Bцhnigk, 2009: 194).

Ці завдання покладаються передусім на культурну антропологію та екзистенціальну філософію. Культурна антропологія, значний внесок до розбудови якої зробив Е. Ротхакер, була спрямована на апологію «тоталізації людського життя у нацистській державі» (Böhnigk, 2009: 195). Ротхакерівська культурна антропологія відрізнялась від культурно-антропологічних досліджень Гелена і Плеснера тим, що вихідним пунктом тут була не людина, а культура. Остання розглядається не абстрактно, а у зв'язку з життям і життєтворчістю. Відповідно, різні культури задають різні стилі життя і навпаки - стилі життя визначають культуру і зрештою - людину (Böhnigh, 2009: 195). Отже, стиль життя та ціннісні орієнтації людини не є чимось приватним, вони задаються державою і нацією, що як наказ не підлягало обговоренню. Так само й цінності, які визначають напрям формування людини, у культурній антропології Ротхакера збігаються з цінностями, встановленими ідеологами націонал-соціалізму і передусім Гітлером.

Націоналістично орієнтовані різновиди філософської антропології, разом з теорією і психологією рас, закріплювали протистав- 
лення надлюдини та недолюдини як представників вищої і нижчої рас на рівні державної політики. Поєднання основних положень німецької філософської антропології з неогегельянськими ідеями «одушевленої держави», «війни як інструменту культури» та імперативу національного самоствердження утворили підгрунтя національно-політичного виховання німецької молоді у вигляді відповідної філософії виховання.

\section{Філософія освіти і виховання Третього рейху у задзеркаллі політичної реальності}

Концептуальні побудови філософії освіти і виховання, як і усе створене на замову тоталітарної «виховної держави», не відрізнялись ані оригінальністю філософського мислення, яке через заідеологізованість поступилося свободою, ані сумлінністю педагогічного розуму. Педагоги, які з позицій сьогодення розглядатимуть ці філософсько-педагогічні розвідки, будуть здивовані відсутністю в них дидактичної проблематики. Філософія «самопідключення» німецьких університетів, розглянута вище, виявилась підспівуванням офіційній ідеології, яка з недовірою ставилась до соціального навчання.

Зрештою активісти у середині німецької філософії, навколо неї та у iї довкіллі надали нового статусу філософській рефлексії над процесами освіти, виховання і соціалізації. Філософія виховання одержала таким чином сумнівне підвищення, перетворившись з тематичного розділу філософської думки на домінуючу філософську дисципліну з досить крихким фундаментом. Ця філософія то виходить за рамки своєї дисциплінарної ідентичності, то різко звужує її кордони. Г. Гізеке виносить вирок такому балансуванню між філософськими амбіціями і ідеологічним диктатом: «Виховання було модним словом при націонал-соціалізмі. Кожний партійний функціонер відчував себе покликаним висловлюватись на предмет виховання, не проходило жодного мітингу без відомої цитати Гітлера ${ }^{1}$.... Але нікому не вдалось розробити загально визнану педагогічну теорію, яку можна було б вважати націонал-соціалістичною (Giesecke, 1999: 12).

\footnotetext{
${ }^{1}$ Йдеться про цитату з «Майн кампф»: «Народна держава ... має зосередити усю свою виховну роботу в першу чергу не на простому накачуванні знаннями, а на формуванні міцного і здорового тіла. Лише потім на черзі буде формування духовних здібностей. Але й тут знову-таки на самій верхівці стоятиме розвиток характеру, особливо підтримка сили волі та сили рішучості, пов'язані з вихованням відповідальної радості, а вже потім наостанок - науковий вишкіл» (цит. за: Ellwein, 1992: 296).
} 


\section{а) Філософія виховання Е. Кріка та ї̈ національно-соціалістичні транс- формації}

У філософії освіти і виховання, яку можна віднести до націонал-соціалістичної , можна виділи два напрямки: народно-політичний (Е. Крік) та політико-педагогічний (А. Боймлер). Вони певною мірою перетинаються, бо мають спільну матрицю - ідеологію націонал-соціалізму, але існують і відмінності, які почасти обумовлені різними біографічними контекстами, почасти розумінням завдань і перспектив філософії освіти і виховання.

Е. Крік почав свою кар’єру з посади шкільного вчителя, був наполегливим автодидактом. Результатом його зусиль у роботі над собою та накопиченого педагогічного досвіду стала книга «Філософія виховання» (1922), за яку він одержав звання почесного доктора Гайдельберзького університету, а у 1933 р. він став ректором «підключеного» університету у Франкфурті на Майні, вважаючи сам акт підключення початком оновлення народної освіти. Ідея народності була надзвичайно близька Кріку. Він, до речі, як вже згаданий вище Гайдеггер, вийшов з низів. Усе «народне» було їм надзвичайно близьке і підштовхнуло їх обох до націоналсоціалізму. За своїм змістом філософія виховання Кріка була надзвичайно близька ідеології націонал-соціалізму, бо звертала увагу на ірраціональні підвалини виховного процесу, несвідомі впливи і зв'язки між людьми, симпатії та антипатії. Оскільки «Філософію виховання» писав педагог без належної філософської підготовки, його філософські розвідки є дещо хаотичними і наївними, хоча й не позбавлені оригінальності. Нетривіальна концепція виховання, розроблена Кріком, визначила трагізм його долі. Г. Гізеке констатує: «У 20 -х роках він зазнав відчуження у багатьох напрямках. Через його наукові публікації відбулось його відчуження від професії і соціального походження; через свою рішучу безкомпромісну позицію він віддалився від близьких йому об'єднань. Йому бракувало розуміння необхідності компромісів; він все більше мислив за схемою «або-або» і оцінював зрештою усі політичні організації по тому, чи послідовно вони чинять опір центру» (Giesecke, 1999: 36). Цілком закономірно, що він, як і Гайдеггер, спочатку був у захваті від ідеології націонал-соціалізму, а після 1936 р. намагався iї удосконалити у своїх численних публікаціях.

Намагаючись удосконалити ідеологію націонал-соціалізму своїми «народно-антропологічними розвідками», Крік переміщує у свої нові праці недоторкане ядро своєї «Філософії виховання», маючи далекоглядні амбіції розробки загальнозначущої теорії виховання з метою покращення людства. Так, ті ж самі теоретичні положення, що були вперше сформульовані у «Філософії виховання», але з посиленою національ- 
но-політичною складовою містяться у працях «Національно-політичне виховання» (1932) та у нарисі «Націонал-соціалістичне виховання, обгрунтоване на основі філософії виховання» (1933), певною мірою також у тритомному творі «Народно-політична антропологія» (1936-1938). Своїм основним завданням Крік вважав обгрунтування ідеї «виховної держави», але не абстрактної, а реалістичної, позбавленої від псевдогуманістичної пропагандистської тріскотні навколо неї, а також втілення цієї ідеї на практиці. 3 цим масштабним завданням він пов’язував також особливе завдання для усіх тих, хто працює у сфері освіти й виховання, формулюючи його у модусі сподівання: «Колись ми таки очистимо педагогіку від буйного наросту фразерства, яке придушує у ній усе мислення (Krieck, 1922: 20). Першим кроком у цьому напрямку він вважав створення філософії виховання, що виходить із самих підвалин народного буття. Мається на увазі етноцентрична міфотворчість «народного становлення німецькості» (Deutschtum) i «формування нової німецької людини, яка з усіма іiі порядками і цінностями стане взірцем та законодавцем для усіх» (Krieck, 1922: 22). Фактично тут відтворюється фіхтеанська модель формування взірцевого народу у закритому просторі держави, що стала своєрідним кліше сучасних німецьких філософськоосвітніх утопій. ${ }^{1}$ Але Крік намагається надати їй більш конкретних рис, звертаючись до расової теорії. Держава у нього виступає «формувальником і приборкувачем народної сили. Задля виконання свого завдання і формування влади вона посилює засадничі расові цінності народу, вирощуючи їх у нових формах, щоб згодом перетворити їх на політичний хребет сильної народності (Volkstum) і обирати з цього прошарку те, що здатне нести на собі державу» (Krieck, 1922: 22). Ідея соціалізму також розгорнуто представлена у праці Кріка. Він завжди знепокоювався проблемою забезпечення рівного доступу до освіти у Німеччині і був переконаний, що націонал-соціалістична держава здатна створити такий соціальний та освітній простір, де пануватиме соціальна справедливість. Щоб узгодити ідею соціалізму з ідеєю народу, Крік розгортає критику еволюціонізму і викриває «метафізичні привиди» на зразок гегелівської системи, хоча він сам широко застосовує категорію становлення, щоправда, поєднуючи іiі з перспективою відкриття «вічного» у підвалинах освіти і виховання. Єдність становлення нового суспільства і вічності «народу», як він вважає, притаманна націям як «найбільш активним одиницям людської історії» (Krieck, 1922: 34).

${ }^{1}$ Детальніше про концепцію «нормального народу» у Фіхте див.: Култаева М. (1988). Философско-педагогические тенденции в современном идеализме. Харьков, «Основа», 24-25. 
Ці наївні і, з філософської точки зору, дилетантські, міркування обумовили структуру його праці «Філософія виховання», яка складається з двох частин. У першій під назвою «Виховання» Крік намагається надати вихованню соціально-філософське обгрунтування, виходячи зі свого розуміння «німецької революції, раси, націонал-соціалізму і його світогляду. А вже у другій частині - «Освіта та школа» - пропонуються теоретичні розвідки щодо «народної реформи освіти та школи», а також підготовки вчительських кадрів. У розгляді цих проблемних полів він спирається на власний педагогічний досвід і цілком реалістично оцінює суспільний статус і людинотворчі можливості вчителя, до діяльності якого зазвичай висуваються підвищені вимоги: «Учитель, - констатує він, $-\epsilon$ пересічною людиною, і зможе сформувати лише таку ж саму пересічну людину, як і сам. ... Навіть якщо він був би цілком вільною особистістю, то спільнота та відомства знайшли б, як затулити йому рота» ( Krieck, 1922: 20).

Відправним моментом його філософсько-педагогічного теоретизування виступає у цілому не нова теза, що люди постійно знаходяться між собою у педагогічних відносинах, а також займаються самоосвітою і самовихованням, навіть не помічаючи цього. Це дає Кріку підстави стверджувати, що інтенціонально спрямоване виховання є лише верхівкою айсбергу, який на мові німецького ідеалізму зветься формуванням людини (Bildung). Цей тип виховання зі своїми раціональними цілями, намірами і методами потребує, на його думку, зв'язку з прихованими ірраціональними життєвими силами, тобто переходу до іншого типу виховання.

Керуючись такими міркуваннями, Крік відходить від лінійного та інтенціонального розуміння виховання, де воля дорослих зрештою визначає долю дітей, що було міцно укорінено в домодерній освітній і виховній традиціях. Нагадаємо, що ще Дільтей, сучасник Кріка, вважав, що виховний і суспільний ідеал задається генерацією тих, хто виховує (див.: Култаєва, 1999: 11). Крік констатує зміну реляцій між поколіннями, коли позиційний авторитет дорослих руйнується через їхню дезорієнтацію і безпорадність у нових контекстах і непередбачуваних ситуаціях. Але відносячи змінюваність до культурно-антропологічних констант, Крік робить їі позаісторичною рамковою умовою усякого виховання. Безперечно, це не звучить в унісон із мріями ідеологів націонал-соціалізму про вічність існування створеної ними держави.

Але Крік пропонує своє розуміння приборкання руйнівного потенціалу змінюваності через спрямування ії енергії на очищення плацдарму для суто германської людинотворчості. Адже без цього суспільство може втратити свої культуру і органічну цілісність, а його освіта і виховання 
відімруть як сухе гілля. Песимістичні сценарії загибелі культури через втрату зв'язку з життєвими силами - це кліше філософії життя, яке у різних формулюваннях повторювалось прибічниками ідеї загибелі європейської культури. Крік пропонує витриману цілком у дусі ідеологем націонал-соціалізму стратегію порятунку європейських цінностей через «тотальну мобілізацію усіх» на ствердження «правильного виховання» і перетворення Німеччини на історично безпрецедентну націю.

Центральну роль у цій стратегії, за Кріком, має відігравати ще не повністю розкритий потенціал функціонального виховання. Нагадаємо, що це так звана «педагогіка для учня ремісника». Таке виховання домінувало, особливо серед нижчих верств населення у середньовічних суспільствах. Але Крік значно ускладнює його структуру, розрізнюючи у ній горизонтальну і вертикальну схеми структурування. Оскільки вертикальна схема вже описана вище, охарактеризуємо стисло горизонтальну, Вона складається з виховання іншими особами і самовиховання, а також з виховання у спільноті і через спільноту, концепт якої, власно кажучи, й перетворює педагогічні спостереження Кріка на різновид популярної філософії освіти, яка відповідала запитам активістів націоналсоціалістичного руху.

Крік розгорає своєрідну діалектику самовиховання, бо як спільнота, так і одиничний ii член виховують самі себе. Розкриваючи цю діалектику, Г. Гізеке підкреслює: «Виховання тут виявляється надзвичайно складним ансамблем впливів та контрвпливів. Крік виділяє чотири рівнозначні форми виховання: 1. Спільнота виховує членів. 2. Члени виховують один одного. 3. Члени виховують спільноту. 4. Спільнота виховує спільноту. ... Найбільш чітко це можна пояснити на прикладі родини: родина як спільнота виховує своїх членів, наприклад дітей, які знову-таки виховують один одного, водночас вони виховують родину як спільноту, підкреслюючи значущість іiі норм для батьків. Як спільнота вони виховують інші спільноти, наприклад сусідські родини» (Giesecke, 1999: 52). Отже, спільноти, як і люди, займаються самовихованням, що підтримує їхні життєві сили, адже вони також є органічними формоутвореннями. Більш того, матриця самовиховання індивіда задається спільнотами, які типологізують та уніфікують людей, які начебто добровільно стають «новими німецькими людьми», або клонами держави. Педагогічним формуванням за наперед встановленим зразком тут повинні охоплюватися не тільки діти, а й усе населення. Більш того, йдеться насамперед про політичну освіту і національно-політичне виховання дорослого населення, під яким малось на увазі відповідне світоглядне виховання. Як досвідчений педагог Крік добре розумів, що цей процес є тривалим і не може прискорюватись волюнтаристськими настанова- 
ми функціонерів Третього рейху, які вважали себе фюрерами відомчого масштабу. Нові партійні призначенці у Третьому рейху так само, як і партійна номенклатура в СРСР, зазвичай не були фахівцями і своїми пропозиціями та діями руйнували все, за що брались і чим керували.

Через розчарування цією політикою у галузі освіти і виховання у 1938 р. Крік вийшов з рядів СС (Giesecke, 1999: 52).

У дусі революційної політичної романтики, розглянутої вище, Крік визначає перспективу формування еталонного «німецького людства» (das deutsche Menschentum), шляхи його самоудосконалення, а також виявляє ворогів, що загрожують цьому процесу. Це індивідуалізм, лібералізм, колективізм, пацифізм, які, на його переконання, є хибними виховними орієнтирами, бо руйнують гармонійні відносини між спільнотами. Ця позиція Кріка почасти обумовлена його сподіваннями на те, що націонал-соціалістичний рух здатний створити такий суспільний лад, коли народ знову може стати органічною цілісністю, але такою, де одиничного будуть розуміти як «члена», де кожний знайде своє місце відповідно до своїх здібностей» (Giesecke, 1999: 48). Треба також зазначити, що положення Кріка щодо виховного потенціалу спільнот, а також ототожнення виховання з процесами соціалізації є уразливими моментами його філософсько-педагогічних поглядів. Адже спільноти у тому сенсі, як їх пропонує розуміти Крік, існують лише за умов їх відтворення у наступних генераціях, але без тиску на дитину, з поступовим підведенням іiі до самостійного засвоєння «народного світогляду». Усі ж інші світоглядні орієнтири, інше бачення перспектив Німеччини і виховання Крік рішуче відкидає як безвідповідальні, як такі, що поглиблюють соціальну нерівність і суперечать соціальній справедливості. Творення органічного «народного тіла», на його думку, є передусім виховним завданням не однієї генерації.

Усе це вимагало нового підходу не тільки до педагогіки, а й до науки у цілому. Поглядам на науку у дусі расологічного редуктивізму, розглянутого вище, Крік протиставляє своє розуміння «вищої освітньої функції науки», де він стверджує конститутивну роль філософії у науковому виробництві. «Без філософського життєвого нерву, - зазначає він, - кожна наука або розпадеться на уламки мертвого спеціалізованого знання, або загрузне у технології» (Krieck, 1936: 2)1 . При цьому особливу увагу він приділяє педагогіці, в якій також давався взнаки технократизм. Але у критиці останнього Крік виходить з ідеї «вічності» виховання, розу-

\footnotetext{
${ }^{1}$ Треба зазначити, що Крік, випереджаючи свій час, намагався практично реалізувати ідею міждисциплінарності. У Гайдельберзькому університеті він створив робочу групу для впровадження у наукові дослідження і навчальний процес міждисциплінарні синтези (Giesecke, 1999: 72).
} 
міючи під цим той факт, що воно є антропологічною константою. Це дає йому підстави - щоправда, дуже хиткі - стверджувати, що виховні дії , як і усі життєві функції і життєві форми відбуваються самодіяльно, але спотворюються у педагогічних теоріях виховання. Крік відстоює ідею створення нової цілісної педагогіки з філософським нервом, або педагогіки цілісної людини. «Така наука, - підкреслює він, - цілком самостійна і не потребує ніякої іншої. Щоправда, вона в дусі цієї ідеї використовує здобутки усіх інших наук; як член духовного організму вона знаходиться з усіма іншими членами у взаємодії давання і отримання. Але жодна з них не може висувати домагання бути основою педагогіки, іiі основоположною наукою. Автономна наука про виховання грунтується виключно на ідеї виховання: вона є провідною думкою і стильовим принципом для картини становлення людства, розширеного у просторі і часі» (Krieck, 1936: 4).

Опрацьовуючи проблемне поле наука-людина-освіта, Крік намагається реалізувати себе також і як освітній філософ та управлінець «підключеного» університету. Підготовкою до такого розширеного проекту стало його масштабне дослідження «Народно-політична антропологія», де він відійшов від офіційно визнаної біологізаторської версії раси і виступив з пропозицією створення «універсальної біології, яка б сприяла подоланню зростаючої диференціації знання і створювала б на своїй основі міждисциплінарні синтези. Такою «універсальною біологією», на думку Кріка, могла стати нова націонал-соціалістична філософія, яка, за його задумом, виростала б із завдань кожного факультету, «поєднуючи багатоманітність різних дисциплін у спільну картину світу, осмислено підносячись над ними, наче баня» (Цит за: Leske, 1990: 111-112).

Семантика оздоровлення суспільства і системи освіти домінує у його численних публікаціях на сторінках нацистських журналів, де Крік намагався обгрунтувати необхідність зміни академічних еліт, посилення в них «народної» складової з метою подолання нерівності шансів доступу до освіти. Він також наполягав на оновленні філософії навчального плану університетів, щоб скасувати домінування природничих наук, зробити навчання міждисциплінарним і покласти край вузькій спеціалізації наукових досліджень, бо німецька наука потребує синтезу, а не диференціації. Але найголовнішою передумовою оновлення Крік вважав розбудову «народної виховної держави» (der völkische Erziehungsstaat) суто дисциплінарними методами, які, на його думку були важливими для «підтримання народної гігієни», тобто уникнення спокус насамперед азійської культури і буддизму. Їх Крік вважав загрозами народній німецькій культурі. Це була прихована полеміка з тими німецькими філософами та літераторами, які вбачали в азійській духовній традиції ресурс 
для оновлення німецької культури (Т. Лессінг, Г. Гессе, елементи давньокитайської філософії запозичив навіть такий прихильник «народності», як Гайдеггер). Щоправда, народна виховна держава навіть теоретично не змогла б здійснювати функції своєрідного культурного фільтру, який передбачався расовою теорією. Адже, за логікою Кріка, кожна національна макроспільнота мала виховувати саме себе, а вишкіл німецьких спільнот менших рівнів у його філософії виховання також мав здійснюватись через самовиховання, але за настановами фюрера, тобто Гітлера. Ця громіздка конструкція вже із самого початку закладала у проект «оновлення» педагогічну дисфункціональність «виховної держави» 3 усіма їі атрибутами народності.

Вказуючи на неспроможність ідеї «виховної держави», Г. Гізеке слушно називає іiі «спокусливою педагогічною думкою», яка була реалізована також і в НДР, де праця, дозвілля, масова комунікація повинні були організаційно і правово слідкувати за тим, щоб людина, де вона не була б, постійно поводила себе «соціалістично». Навіть органи безпеки - включаючи штазі - мали завдання проводити з порушниками виховні бесіди у випадку неконформної поведінки» (Giesecke, 1999: 62). Схожі приклади, що свідчать про крах спроб побудувати виховну державу, можна навести також із історії СРСР, відлуння якої й дотепер даються взнаки на усьому пострадянському просторі, хоча стрімкий розвиток медійної культури практично унеможливлює тотальний контроль за кожною людиною, не говорячи вже про вибір на користь тотального світогляду, навіть у його «народній версії.

Теж саме проблемне поле, але з іншим розташуванням акцентів і цілковито іншою аргументацією представлено у філософії освіти та виховання А.Боймлера.

\section{б) Філософія освіти і політична педагогіка $А$. Боймлера}

На відміну від Кріка, Боймлер зробив типову академічну кар’єру і мав систематизовані філософські знання. В університетах Мюнхена, Бонна і Берліна він вивчав історію мистецтва, філософію, побував солдатом на фронті під час Першої світової війни, а після захисту габілітаційної праці у 1924 р. працював у Дрезденській вищій технічній школі, де у 1929 р. після габілітації був обраний звичайним професором кафедри філософії і педагогіки. Предметом його наукових інтересів у ці роки були філософські і політичні погляди Ніцше, а також містицизм німецьких романтиків із семантиками землі, народу, природи, походження, витримані в ключі ідеологем Третього рейху. У 1933 р. він вступив до НСНРП ${ }^{1}$, в тому

\footnotetext{
${ }^{1}$ NSDAP - Націонал-соціалістична німецька робітнича партія
} 
ж році був запрошений до Берлінського університету, де отримав професуру з політичної педагогіки, а після участі у акції спалювання книжок, ворожих німецькому духу, очолив новостворений Інститут політичної педагогіки. Цей Інститут мав займатись розробкою наукових засад нового державного виховання та управління.

Боймлер з притаманним йому інтелектуальним снобізмом був змушений сидіти одразу на двох стільцях: з одного боку, йому була близька ніцшеанська проблематика людини і влади, молоді і тілесної краси, людського буття в екстремальних ситуаціях, одержання знання про «темний бік» людської природи, а з іншого - доводилось займатись більш вузькою проблематикою Інституту і конкретними управлінськими справами.

Розглянемо ці два аспекти його теоретичної та ідеологічно-управлінської діяльності. Своєрідним компромісом у даному випадку є поєднання в одній площині проблематики людині та історії, що дозволяє 3 більшою термінологічною чіткістю, ніж це має місце у Кріка, здійснити концептуалізацію так званої «обов'язкової» ідеологічної програми націонал-соціалізму, яка була зосереджена на проблемному полі політичного народу і расової теорії. Останні у Кріка були у центрі теоретизування, у Боймлера ж вони опиняються на периферії. Здійснюючи діагностику свого часу, він зазначає: «Вже більш неможлива культура духу, бо наступила культура сили» (Baeumler, 1937: 127). У цьому, на його думку, відкриваються нові можливості не тільки для німців, а й усієї Європи, діалектика якої розкривається крізь культурний вимір сили. Під силою тут розуміється не насилля і вседозволеність, а воля, активізм, характер. Формулою цих змін, за Боймлером, $\epsilon$ «римська культура, поєднана з германською силою», бо «Європа не є чисто латинським, чи чисто германським поняттям, вона є діалектичним поняттям» (Baeumler, 1937: 56).

У цій формулі криється приховане нагадування про імперію Карла Великого і водночас возвеличення творчого варварства германської раси, яка руйнує усі стереотипи урбаністичної культури з орієнтацією на матеріальне. На цій основі Боймлер розробляє свою концепцію активної, діючої людини, яка є «не тільки природною, а й історичною істотою» (Baeumler, 1937: 76). Але розуміння історичності тут є специфічним. Історичність підкреслює релятивізм значущості теоретичної і практичної людини. Теоретичною, тобто умоглядною, людиною тут виступає іiі неогуманістична концептуалізація, яка висуває домагання на монополізацію освіченості. Через це солдат традиційно став вважатись неосвіченою і бездуховною людиною. Революція націонал-соціалізму у розумінні людини, за Боймлером, полягає у заміні ідеалу освіченої людини на образ політичного солдата. 3 цим образом пов'язується 
«справжнє чоловіче виховання» за межами урбаністичного простору $\mathrm{i}$ світу культури, де відбувається формування героїчної особистості. Але особистістю в рамках ідеології націонал-соціалізму стає лише та людина, яка служить спільноті (Leske, 1990: 183).Особистість загартовується у таких германських чоловічих союзах, де, на відміну від «жіночо-демократичних» об’єднань, формуються характер, воля і тіло.

Філософію виховання Боймлера, у центрі якої знаходиться політичний солдат, завжди готовий до тотальної війни, доповнює філософія тілесних вправ як антропологічне і політичне обгрунтування необхідності не просто загартовувати, а й виховувати та формувати тіло політичного солдата. Ця суто маскулінна філософія, як і усі інші «нові» філософські обгрунтування виховання, витримана у дусі ідеології націонал-соціалізму, і підпорядковується настановам тотального народного світогляду. Через це Боймлер вказує на необхідність розрізнення раціоналістичного інтернаціонального спортивного руху, який підтримують соціал-демократія і профспілки, від справжнього «германського» тренування тіла для боротьби, яка є трибом життя для справжнього солдата. До категорії «справжнього» потрапляє «ірраціонально спрямований гімнастичний рух», проголошений Боймлером проявом народної моральності та нової релігійності ${ }^{1}$. Фактично ця «нова релігійність» була запрограмована ще Гітлером на самому початку націонал-соціалістичного руху. Наведемо його директиву щодо пріоритетного значення фізичного виховання: «Народна держава ... має зосередити усю свою виховну роботу в першу чергу не на простому накачуванні знаннями, а на формуванні міцного i здорового тіла. Лише потім на черзі буде формування духовних здібностей. Але й тут на самій верхівці знову-таки стоятиме розвиток характеру, особливо підтримка сили волі і сили рішучості, пов'язані з вихованням відповідальної радості, а вже потім, наостанок - науковий вишкіл» (цит. за: Ellwein, 1992: 296). Отже вже у «Меin Kampf» була задана канва розбудови філософії виховання і освіти на основі расової теорії з основним акцентом на тілесності та формуванні характеру, яку Боймлер лише посилює за рахунок філософської аргументації. Так, він свідомо відходить від гумбольдтіанського ідеалу всебічно і гармонійно розвинутої людини i вводить поняття «обмеженої здатності людини до формування» (beschrдnkte Bildsamkeit) на основі спостережень здатності або нездатності людини займатись спортом і виконувати гімнастичні вправи, залучатись до командних видів спорту. При цьому спортивність німця протиставля-

\footnotetext{
${ }^{1}$ Спроби сакралізації та теологізації спорту спостерігаються і у сучасній культурі. Як зазначає Кр. Бауер, «футбол є теологічно релевантним навіть і без його релігійного піднесення» (Bauer, 2017: 48).
} 
лась неспортивності та неспритності єврея, що у різний спосіб обігравалось пропагандою і відображувалось у карикатурах.

Присутність расової складової відрізняє «філософію тілесних вправ» Третього рейху від концептуалізації фізичного виховання на основі теорії комуністичного виховання, хоча фізична досконалість також і в комуністичній ідеології була індикатором перевершення інших народів через створення досконалого фізичного тіла, репрезентанта радянської людини, яке ототожнювалось з політичним. Це можна простежити на прикладі організації і проведення Олімпійських ігор у фашистській Нiмеччині (1936) та в СРСР (1980), а також на прикладі помпезних Зимових Олімпійських ігор у Сочі (2014р.). Притаманна тоталітарним суспільствам політизація міжнародних спортивних змагань, особливо в ігрових та командних видах спорту, завжди виходить з визнання колективного тіла і національного командного духу. Основний акцент тут переноситься з виявлення фізичних можливостей людини на демонстрацію досягнень нації, що завжди використовували ідеологи Третього рейху як у політичній пропаганді, так і у вихованні. Німецькі спортсмени, які успішно виступали у міжнародних змаганнях, уособлюючи надлюдину, тим самим демонстрували вищість німецької нації. Гітлер, виходячи з міфу про вищість німецької раси, вважав державною справою спорт і фізичне виховання, оздоровлення та загартовування дітей. Щоправда, мотивація такого ставлення до фізичної культури була передусім геополітичною. Спорт ідеологи Третього рейху розглядали як тренінг для подальших цілком реальних битв за розширення геополітичного простору рейху. За Гітлером, найбільш придатним для підготовки підростаючого покоління до тотальної війни був бокс, який вчить тримати удар, деморалізувати суперника і здобувати перемогу навіть у безнадійних ситуаціях. Ідеальний націонал-соціаліст, як його уявляли собі конструктори цього ідеального типу, мусив бути «твердим і вміти зносити удари. На це було націлене формування характеру у новій державі, яка рішуче відмовлялась формувати «колонію мирних естетів та тілесних дегенератів», де чоловіки переймають жіночі моделі поведінки» (Цит. за: Giesecke, 1999: 25).

Ці настанови Боймлер переносить у площину своєї філософії освіти та філософської педагогіки, які є продовженням його антропологічно орієнтованої філософії виховання, в центрі якої знаходиться не дитина, а молодь з притаманним їй потенціалом оновлення. Використати цей потенціал на благо нації стає основним завданням нацистської політичної педагогіки. Віщування Боймлера витримані цілком у дусі Гітлера: «Народу, юність якого в’яне за зошитами та книжками, державі, чия молодіжна команда зростає без ентузіазму, що пробуджується лідерськими 
натурами, загрожує небезпека виродитись у суспільство заможних або освічених філістерів» (Вaeumler, 1937: 150). Але молодь у міфологізованих конструктах політичної педагогіки Третього рейху має щось на зразок імунної системи проти такої деградації. Взагалі наявність позірних захисних механізмів у народній державі, які начебто діють автоматично, само-діяльно, є своєрідним самонавіюванням ідеологів націонал-соціалізму, їхньою охоронною грамотою від самих себе. Завдяки дії такого механізму, як зазначає Боймлер, молодь чинить спротив принципу ретроспективної освіти, коли іiі змушували наповнювати себе старими і непотрібними знаннями, вона руйнує стару школу і вимагає випереджальної освіти. Сама ця вимога є справедливою, вона ще з більшою гостротою лунає й досі. Але проблема полягає у тому, що з прискоренням наукового виробництва і впровадженням нових технологій майбутнє стає все більш невизначеним, а нові знання застарівають вже на рівні їхньої дидактичної трансляції.

Але Боймлер розглядає проблему оновлення школи і освіти цілковито в іншій площині. Він пропонує замінити загальноосвітню школу на політичну, мотивуючи це тим, що зрештою настав ії час, а молодь вже не може і не хоче чекати оновлення і закликає почати його тут і зараз. Нова школа повинна розвивати сили молоді, стати «народною світоглядною школою», зрозуміло, «під захистом держави» (Baeumler, 1937: 105). Погляди Боймлера на нову школу є суперечливими. Так, з одного боку, вона має стати «Політичною», а з іншого - бути «життєвою формою». Поєднати ці дві вимоги, як хоче Боймлер, надзвичайно важко, адже він пропонує не освітню метатеорію, а філософську стратегію перебудови реально існуючих освітніх інституцій. А в цій оптиці, як зазначає сам Боймлер, необхідно здійснити приборкання руйнівного ентузіазму молодих активістів: «Молодь повинна також навчитись чекати», - зазначає він, залучаючи терплячість до вправ, необхідних для формування характеру» (Baeumler, 1937: 80). При цьому він, так само як і Крік, закликає педагогів обережно ставитись до особистості учнів та студентів і застосовувати лише опосередковані форми впливу, уникаючи наказів та муштри. Він підіймає також проблему «нової педагогічної освіти» для підготовки оновленого викладацького складу, але ця освіта тут також несе на собі відбиток романтики ${ }^{1}$.

На розробці стратегії нової освіти, а також на політизації гуманітарних наук та людинознавства була зосереджена діяльність Інституту політичної педагогіки, про який вже згадувалось вище. Необхідність змін в німецькій науці Боймлер виводить не з особливостей об’єкту дослі-

${ }^{1}$ Докладніше див. (Giesecke, 1999: 62). 
джень, а керуючись виключно політичною доцільністю інтеграції названих вище наук у політичну ідеологію націонал-соціалізму. Міждисциплінарні синтези, безперечно, відкривають нові горизонти для розвитку наукових досліджень, але їх уразливим моментом є незахищеність від суб'єктивістських інтерпретацій і політизації, коли логіка переконання сама починає встановлювати дослідницькі пріоритети, норми і критерії успішності. 3 цієї логіки виходить і Боймлер у своїх амбіціях виступити у невластивій йому функції: бути організатором наукового виробництва. «Нова дійсність, - зазначає він, - ставить перед гуманітарними науками нові завдання. Нова німецька людина, політична людина, з’являється у космосі тих наук, які можна назвати «науками про державу» у їх широкому розумінні. Головне завдання Інституту політичної педагогіки полягає у тому, щоб посилити політичний зміст наук, які розпорошено викладаються на філософському і юридичному факультетах, і тим самим надати цим наукам нове живе дихання» (цит за: Leske, 1990: 216).

Дослідження у цьому інституті проводились у трьох напрямках: філософія і педагогіка, політичні системи, науки про державу. За підсумками цих досліджень інститут рекомендував впроваджувати студентське самоуправління, підтримувати тісні «товариські» зв’язки між викладачами і студентами на зразок «справжньої спільноти». Університет і школу Боймлер вважав місцем формування духу живої народної спільноти, частиною народного та історичного життя. Багато уваги в рамках Iнституту приділялось популяризації заідеологізованої філософії освіти і виховання, видавалась періодика. Серед періодичних видань інституту треба особливо виділити «Міжнародний журнал з проблем виховання» та «Світогляд і школа», де припускались дискусія і полеміка. Безперечно, вирішальну роль у спрямуванні досліджень в Інституті відігравали погляди самого Боймлера, його уявлення про «тотальну війну» як боротьбу між двома життєвими системами і відповідно - двома культурами. На це, зокрема, звертає увагу Г. Гізеке. Він зазначає, що урбаністичній, економіко-матеріалістичній культурі, де регулятивом виступає мода, Боймлер протиставляє маскулінно-героїчну життєву форму як прояв «германізму чоловічого єднання» (männerbündischer Germanismus), вважаючи цілеспрямоване формування такої спільноти основним завданням політичного виховання, покликаного конституювати не тільки виховну, а й «войовничу силову державу» (Giesecke, 1999: 81-82).

Архаїзація суспільної свідомості, намагання не стільки реконструювати, скільки відродити германські традиції як своєрідну матрицю автентичного державотворення, зберігаючи при цьому усі переваги прискореної індустріалізації, надали, як відомо, поштовх появі у націоналсоціалістичній педагогічній, філософській і соціологічній літературі 
досить одноманітних кримінальних соціальних і педагогічних утопій. Жінкам в них відводилась маргінальна позиція обслуговування чоловічих спільнот та виконання репродуктивних функцій, в тому числі й у їх раціоналізованому і принизливому варіанті.

\section{в) Культурно-естетичний поворот у філософії формальної $і$ нефор- мальної освіти}

У практиках неформальної освіти поступово руйнуються гендерні преференції ідеології Третього рейху, орієнтовані на «солдатську форму життя». Коедукація, вилучена зі шкільної організації освітніми функціонерами Третього рейху, поступово починає відвойовувати свій простір. Разом з цим треба зазначити, що педагоги Третього рейху у цілому поділяли думку Гітлера, що «німецька дівчина є передусім підданою держави, а громадянкою стає лише після взяття шлюбу (Knopp, 2000: 95). Закріпленню цього стереотипу домодерного мислення чимало сприяла діяльність «Спілки німецьких дівчат» (BMD) як особливого підрозділу гітлерюгенд. 31939 р. усі дівчата обов'язково мали відвідувати щотижневі вечорниці у спеціальних приміщеннях на зразок радянських будинків культури (Heimabende), а також спортивні заняття, щоб ставати носіями і трансляторами націонал-соціалістичного виховання» (Kammer, Bartsch, 1992: 29). Докладніше про це йдеться у доданих нижче перекладах спогадів Г. Цезар і Л. Шмідт.

Рефеодалізація суспільного життя як суттєва риса гітлерівського режиму не менш чітко, ніж в інших сферах, виявилась в спробах практичного реформування шкільної освіти, виходячи з містичних глибин німецького духу та цілком раціональної вимоги щодо посилення їхньої інституційної функціональності. Розглянемо це на прикладі елітних шкіл Адольфа Гітлера, які були засновані рейхсфюрером з питань молоді Балдуром фон Шірахом і рейхсляйтером з організаційних питань Робертом Лаєм. Обидва не мали ані педагогічного досвіду, ані досвіду управління освітніми інституціями. Але за канонами політичної романтики вони як молоді функціонери були за віковими і расовими характеристиками найбільш придатними кандидатурами нових лідерів для проведення інноваційної, але бездумної і безвідповідальної політики в освіті, не замислюючись над їі наслідками.

3 ім'ям фон Шираха пов'язаний мистецько-культурний поворот у педагогіці Третього рейху (1936 р.). Він пропонував, не відходячи у цілому від ідеології націонал-соціалізму, зосередитись на залученні німецької молоді до культури, в тому числі й до побутової. Революційному запалу і пафосному героїзму Боймлера тут протиставляється компромісне рішення часткового повернення у політичне виховання «національно- 
буржуазної культури». Ширах намагався також доповнити буржуазними культурними практиками солдатський стиль життя молодих активістів, вважаючи ці практики культурним досвідом, який треба засвоювати, щоб запобігти сповзання у варварство. Адже ідеал героя, який віддає життя за фюрера і Німеччину, зводив етику служіння до екстремальних випадків буття перед обличчям смерті і зовсім не орієнтував молодь на мирне життя в спільноті, яка також займала центральне місце в ідеології Третього рейху. Солдатське життя, яке на етапі націонал-соціалістичного руху було моделлю функціонального виховання молоді, потребувало ушляхетнення, внесення до нього життєвих барв, щоб зберегти свою привабливість. Старомодну «народно-політичну антропологію» Кріка після його самоусунення від активної політико-педагогічної діяльності (1936 р.) Ширах доповнює вибірковими елементами педагогічно апробованої буржуазної культури, які на цьому тлі навіть справляють враження освітньо-виховних інновацій. Він робить основний акцент на емоційній стороні освітніх і виховних практик. Освіта і виховання, за його задумом, мають бути насиченими позитивними емоціями і здійснюватись у «школах самовиховання». На заняттях повинна домінувати групова робота, співпраця вчителя та учнів. Навчальний простір тут пропонується конституювати, виходячи з потреб учнів, при цьому оптимальною моделлю розташування учнів вважалась підкова з натяком на співпрацю агентів та адресатів в освітньому просторі (Giesecke, 1999: 204). Гумбольдтіанський ідеал всебічного і гармонійного формування людини, свого часу розкритикований Шпрангером і Боймлером, також неочікувано нагадує тут про себе вимогою поєднання культурних технік, необхідних для фізичного, художньо-музичного та духовного розвитку німецької молоді. Синтез морально-етичного та естетичного виховання у даному випадку розглядався інструментально - як засіб примноження внутрішніх креативних сил німецької молоді.

Але бракувало вчителів, необхідних для реалізації таких планів, занадто амбітних і досить незвичних для закоснілих функціонерів Третього рейху. Вимога дружніх і навіть приятельських педагогічних відносин між педагогами та учнями у «новій школі» виявилась у ті часи майже нездійсненною місією, бо німецьке суспільство ще не було готовим до побратимства у школах та університетах, хоча функціональне виховання, на якому наполягали педагогічні авторитети тоталітарної «виховної держави», могло здійснюватись тільки у таких умовах. Вчителі, здатні на це, були винятком у німецькій авторитарній педагогічній традиції. Поєднати дисциплінарні заходи з духом товаришування та успадкованими від попередньої традиції корпоративними студентськими звичками було складно. У нових навчально-освітніх закладах ці пропозиції сприй- 
мались як дезорієнтири, що призводило до духовної деградації і зовсім не до очікуваного саморозвитку особистості учнів. Їх самостійність проявлялась здебільшого негативно, «народний світогляд» перетворювався на аксіологічний нігілізм і знищення моральних важелів впливу на молодь, особливо на розбещених активістів.

Мислення бажаннями і гаслами, успадковане культурними реформаторами Третього рейху від активістів націонал-соціалістичного руху часів Ваймарської республіки, виявилось руйнівним для німецької освіти, яка зберігалась лише на тих острівках гуманізму, де існував імунітет проти зваблень політичної романтики. Ті ж школи, які створювались безпосередньо за ініціативою функціонерів Третього рейху, були живим унаочненням внутрішніх протиріч тоталітарної держави. Не зайве зауважити, що більшість з цих шкіл була заснована всупереч негативного ставлення до них з боку Б. Руста, рейхсміністра з питань науки, виховання і народної освіти, який до своєї партійної кар'єри досить довго працював у системі управління навчальними закладами і передчував катастрофічні наслідки проектів на зразок інновацій Шираха. Елітні школи, які мали готувати майбутніх фюрерів різного рангу, за своєю організаційною формою, курикулярними опціями і виховними стратегіями демонстрували усі внутрішні суперечливі моменти націонал-соціалістичної філософії освіти і виховання. Так, школи Адольфа Гітлера підпорядковувались не відповідному міністерству, а партії. Гітлер не тільки дозволив цим школам носити своє ім'я, але й вважав їх важливим елементом, необхідним для підтримки диктатури. Це були середні школи, для навчання в них відбирали 12-річних хлопців за рекомендацією гітлерюгенд, щоб у подальшому сформувати з них лідерів, в тому числі й для заміщення партійної верхівки, чому, звісно, чинився опір. Навчання тут було безкоштовним. Здібності і розумовий розвиток майбутніх учнів спочатку не брались до уваги, хоча згодом автори цього сумнівного проекту вже вказували своїм шкільним адміністраторам на необхідність відбирати підготовлених і здібних підлітків. Але, мабуть, найгіршою вадою діяльності таких шкіл була нездатність їхньої адміністрації планувати навчально-виховну роботу, розробляти програми і навчальні плани. Основний акцент у навчанні був зроблений на серцевині ідеології німецького фашизму - вченні про раси, на міфологізованій німецькій історії і передусім на книзі Гітлера «Майн кампф», де жанр виховного роману, поширений в німецькій белетристиці, поєднувався з популістськими ідеями та настановами, як підкорювати маси і приймати рішення (Koschorke, 2016: 7-8). На основі цієї «Біблії націонал-соціалізму» були розроблені підручники та посібники для підготовки майбутніх лідерів, де основна увага приділялась формуванню нордичного характеру, волі та етиці слу- 
жіння. Не менш важливим був інший блок - спорт і військова підготовка. В методичному аспекті спорт і тілесні вправи, на відміну від ідеологічного блоку, були продумані і систематизовані, бо тут продовжувалась традиція довійськової підготовки вільгельмінівської Німеччини. Але у цілому елітарність такої освіти була позірною, бо після закінчення цієї школи випускники зовсім не просувались кар'єрними сходинками, одержуючи лише військове звання і кваліфікацію солдата.

Солдат як символ духу Третього рейху і солдат як професія мають принципові відмінності, бо професіоналізація цього символу звужувала простір вторинної соціалізації рамками наказу і слухняності. Але засвоєння солдатської професії, з якої починав Гітлер, в цих школах супроводжувалось етосом боротьби. Героічний реалізм солдата, його прагнення до самоперевершення, постійна готовність до самопожертви певною мірою були у гегелівському сенсі «зняттям» солдатчини як специфічної форми буття. В освітніх опціях і виховних стратегіях Третього рейху твердість і непохитна рішучість урівноважувались вихованням духу товариськості і бойового побратимства, тим самим учнівський колектив з перспективою лідера (фюрера) і дійсністю солдата цілком у дусі філософії виховання Кріка перетворювався на замкнуту у собі спільноту, але $з$ можливістю підключення до інших спільнот, які конституюються за принципом перманентної боротьби за німецькі національні цінності.

Схожі тенденції можна простежити в інституційній розбудові елітних національно-політичних виховних закладів (NPEA) інтернатного типу для старшокласників, безпосередньо підпорядкованих Русту. Вони продовжували прусські та баварські традиції , а на організаційній основі державних освітніх закладів досить органічно трансформувались в національно-політичні навчальні установи (Napola), які були, щоправда, платними, але доступними.

Дидактичним девізом усіх таких закладів була «любов до боротьби і готовність до героїчної смерті». Така любов до боротьби перетворювала останню на самоціль. Боротись, а не жити у мирі і злагоді, знищувати, а не будувати стало дуже швидко основним життєвим принципом після захоплення влади у Третьому рейху. Він протиставлявся ідеалам старого суспільства, бюргерські звички якого нещадно висміювались функціонерами та архітекторами нового режиму. Деструктивні риси цієї тоталітарної держави не в останню чергу були обумовлені нездатністю режиму виконувати свої обіцянки, які давались народу. Розрахунки на війну як на ресурс життєзабезпечення і підвищення соціальних стандартів у черговий раз виявилися марними, а патерналістські амбіції держави дуже швидко були замінені такими орієнтирами як самоорганізація і самопоміч, а також кримінальною політикою «елімінації непотрібних їдоків», 
тобто масових знищень усіх тих, хто вписувався у рубрику «життя, не варте для життя», тих, хто вважався асоціальним елементом. Ця політика демонструвала також тенденції усувати населення похилого віку, не здатне працювати» (Mommsen, 1991: 411).

Порушення міжпоколінної справедливості, зневажливе ставлення до старшої генерації в даному випадку не набуло форми відкритого конфлікту між батьками і дітьми, бо за формальною ознакою і тими наративами, які це суспільство розповідало само про себе, воно належало до такого типу культури, де молодь міняється ролями з батьками і певною мірою виховує їх. Безперечно, ця модель занадто спрощує візерунок взаємозалежностей у модерних суспільствах, але фіксує прагнення ідеологів націонал-соціалізму позбутись дорослого населення як зайвих свідків своїх злетів і падінь, як потенційних носіїв інакшого мислення в рамках тієї ж самої німецької культури зі справжніми, а не фіктивними життєвими традиціями.

Симулякри буттєвої укоріненості, закріплені у метафориці і габітусі німецьких фашистів, зрештою виявились декорацією їхньої безрідності і віддаленості від життєвих інтересів народу, від імені якого і начебто для якого чинились злочини проти людства. Одним з таких симулякрів були так звані товариські відносини між вчителями та учнями. Так, у школі Адольфа Гітлера вчителі цілком у дусі описаних вище вимог Шираха позиціонували себе «добрими товаришами» учнів, відкриваючи перед ними усі підводні течії кар'єри солдата, але паралельно заохочували дітей до згубних звичок. Гітлеру ж у таких гібридних авторитарно-партнерських педагогічних відносинах відводилась, в залежності від виховної ситуації, роль або батька, або старшого брата (Kater, 2005: 15).

В елітних навчальних закладах Третього рейху була порушена також обіцянка щодо рівних шансів доступу до освіти. Діти робітничого класу завершували свою освіту в школі Адольфа Гітлера і ставали солдатами, «фюрерство» яких обмежувалось жорстким поводженням з «нижчими расами» і у підкоренні фюрерам вищого рангу, тим самим реалізуючи одне із головних завдань політико-педагогічного виховання - самопримус. Просування до середнього класу учням цих закладів унеможливлювалось через їхню елементарну неосвіченість, в той час як в традиційних німецьких школах навіть у робочому середовищі підтримувався досить високий рівень освіти, включаючи навіть гру на музичних інструментах. В мемуарах ексканцлера ФРГ Гельмута Шмідта і його дружини Локі Шмідт детально описується їх життя і навчання у Гамбурзі при гітлерівському режимі. Таких спогадів начебто з паралельного світу існує чимало. В них формувались сили спротиву і нове розуміння долі країни. 
Випускники шкіл Адольфа Гітлера формально мали ставати резервом для партійної еліти за умов продовження навчання у так званих «орденбургах» (орденський замок), сама назва яких мала пробуджувати у юнаків почуття власної приналежності до середньовічного лицарства. Цей тип вищої школи був гібридом між військовою академією та традиційним університетом (Kater, 2005: 49). Але через брак викладачів і коштів цей проект так само, як і школи Адольфа Гітлера, зазнав самознищення. Тепличними умовами для вихованців вирізнялась вища школа для дітей можновладців рейху (NS - Deutsche Oberschule Starnberger $\mathrm{See})$. Це був інтернат у мальовничому місці на Штарнберзькому озері. У ньому більше уваги приділялось відпочинку і розвагам, ніж навчанню. На шкільному подвір'ї можна було грати в гольф, займатись парусним спортом. Поганих оцінок тут нікому не ставили, особливо коли куратором закладу став Рудольф Гесс, прихильник антропософських поглядів Рудольфа Штайна та Вальдорфської педагогіки (Kater, 2005: 49). У школі цього типу особливо чітко виявились усі проблеми і негаразди освітніх експериментів націонал-соціалізму. Це передусім безграмотність, брак дисципліни, відсутність поваги до досвідчених офіцерів, викладачів та священників, гомосексуалізм і гвалтування жінок (Kater, 2005: 50). Безперечно, ці факти приховувались, бо керівництво закладу погрузло в корупції та зловживаннях, а викладацький склад у переважній більшості був некомпетентним і підміняв освіту здобуттям практичних навичок та досвідного знання (Kater, 2005: 50).

У цілому національно-політичні навчальні заклади, незалежно від їх типу, як вже зазначалось вище, були чоловічими. Культура і атмосфера, яка в них панувала, нагадувала студентські корпорації XIX-го століття та солдатське побратимство часів Першої світової війни. Щоправда, серед такого роду закладів існували три для дівчат, але це не змінювало антифеміністську позицію правлячої верхівки націонал-соціалістичної держави. Нижче наводяться спогади жінок, які пройшли організаційні освітні тортури у часи націонал-соціалізму.

\section{Висновки}

У підсумку треба зазначити, що філософія освіти і виховання Третього рейху з ії амбіціями на оновлення суспільного життя була модерною антиутопією з обмеженою варіативністю і негативними верифікаціями. Попри інтенсивну пропагандистську роботу серед німецької молоді, в освітніх інституціях гостро відчувався брак систематичної виховної роботи, яка замінювалась навіюванням і маніпулятивними техніками, що зрештою трагічно вплинуло на долю так званих «дітей Гітлера». Само- 
стійність і самодіяльність, якої вимагали ідеологи Третього рейху від молоді, була лише гаслом і свідчила про їхню педагогічну безпорадність. Філософія виховання і освіти, яку пропонували ідеологи націонал-соціалізму, виконувала не орієнтаційну, а інструментальну функцію, намагаючись автоматизувати навчально-виховний процес і зробити самих дітей водночас його агентами та адресатами, чому сприяла містифікація образу фюрера та його репрезентацій. Одним із парадоксів ідеології Третього рейху як дисциплінарно-виховної держави було те, що ії філософія виховання, до речі, так само, як і теорія комуністичного виховання, конструювала свою уявну соціальну і педагогічну реальність, займаючись педагогічним фікціоналізмом. Цьому сприяла зосередженість виключно на онтологічних засадах ідеологічно ефективної функціональності виховання, яке зводилось до технік маніпулювання і самонавіювання, розглядалось як підготовка до «боротьби» і формування стереотипних типів особистості, яка б відповідала запитам агресивної національної спільноти Третього рейху. До того ж, расова теорія ще більш, ніж вчення про історичну місію пролетаріату, звужує горизонти виховання, стискує його простір рамками партійних інтересів, затримуючи духовний розвиток молоді у стані духовної коми і штучної перенасиченості виховними заходами з пустопорожнім змістом, що є одним із симптомів педагогічної занедбаності і краху так званої «нової» системи освіти горезвісної «виховної держави».

\section{Посилання / References}

Гюнтер Г.Ф.К. (2005). Избранные работы по расологии. Пер. с нем. М: Белые альвы.

Култаева М.Д. (1988). Философско-педагогические тенденции в соременном идеализме. Харьков: Вища школа.

Култаева М. (1999). Категория «Bildung» в немецкой философской традиции, или размышление о смысле и предназначении образования. Постметодика, 1, 8-13.

Култаєва М.Д. (2002). М. Гайдеггер у спогадах колег та учнів. В: Мартін Гайдегzер очима сучасників. К.: Стилос, 3-23.

Култаєва М. (2006). Макс Горкгаймер - патріарх Франкфуртської школи. В: Макс Горкгаймер. Критика інструментального розуму. Перекл. з нім. М. Култаєвої. Київ: ППС-2002.

Култаєва М.Д. (2017). Освіта та іiі деформації у сучасній культурі: до актуальності теорії напівосвіти Т. Адорно у сучасних соціокультурних контекстах. Філософія освіти. Philosophy of Education, 1(20), 153-195. URL: www.philosopheducation.com

\section{References}

Abendroth, W. (1986). Die deutschen Professoren und die WeimarerRepublik. In: Hochschule und Wissenschaft im Dritten Reich. Hrsg. J. Tröder. Frankfurt am Main, 11-25.

Baeumler, A.(1937). Politik und Erziehung. Berlin: Junker und Dünnhaut.

Bauer, Chr. (2017). Fußball als theologischer Ort. In: Herder Korrespondenz, 11, 44-48. 
Becker F. (1933). Amerikanismus im Weimar. Sportsymbole und politische Kultur 19181933. Wiesbaden: Deutsche Universitдtsverlag.

Bernstein, B. (2003). Class, Codes and Control.Volum 111: Towards a theory of educational transmission. London: Routledge \&Kegan Paul.

Böhnigh, V. (2009). Nationalsozialistische Kulturphilosophie. In: Philosophie im Nationalsozialismus. Hrsg. Jörg Sandkühler. Hamburg F. Meiner, 191- 219.

Brecht, B. (1980). Rede auf dem 1. Internationalen Schriftstellerkongress zur Verteidigung der Kultur. Paris 1953. In: Brecht. Ein Lesebuch für unsere Zeit, 473-477.

Dahrendorf, R. (2006). Versuchungen der Unfreiheit. Die Intellektuellen in der Zeiten der Prüfung. München: C.H. Beck.

Grosser, F. (2011). Revolution denken - Heidegger und das Politische. 1919-1969. München: Beck.

Günther, H. F. K . (2005). Selected Works on Rasology [in Russian].

Eilenberger, W. (2014). Heidegger. Ein gefährlicher Denker. In: Philosophie Magazin, 03, 69-70.

Elias, N. (1992). Studien über die Deutschen. Machtkämpfe und Habitusentwicklung im 19. und 20. Jahrhundert. Frankfurt am Main: Suhrkamp Taschenbuch.

Ellwein, T. (1992). Die deutsche Universität. Vom Mittelalter bis zur Gegenwart. Frankfurt am Main: Hain.

Farias, V. (1989). Heidegger und der Nationalsozialismus. Frankfurt am Main: S. Fischer.

Friedemann, B. (1994). Lexikon III. Reich. Hamburg: Carlsen Verlag.

Giesecke, (1999). Hitlers Pädagogen. München: Weinheim. URL: www.hermann-giesecke. de/hitler.pdf

Grüttneer, M. (2009). Universität und Wissenschaft in der nationalsozialistischen Diktatur. In: Philosophie im Nationalsozialismus. Hrsg. Jörg Sandkühler. Hamburg F. Meiner, 31-56.

Günther, H.F.K. (1933). Volk und Staat in ihrer Stellung zu Vererbung und Auslese. München: J.F. Lehmann.

Günther H.F.K. (1933). Das Verbot von Mischehen mit Juden. München: J.F. Lehmann.

Heidegger, M. (2014). Die Selbstbehauptung der deutschen Universität. In: Sammelbeilage N15 von Philosophie Magazin, 03.

Horkheiner, M., Adorno, Th. (1987). Dialektik der Aufklürung. In: Max Horkheimer. Gesammelte Schriften. Bd.5. Frankfurt am Main: S. Fischer, 13-238.

Horkheimer, M. (1987). Vernunft und Selbsterhaltung. In: Max Horkheimer. Gesammelte Schriften. Bd.5. Frankfurt am Main: S. Fischer, 320-355.

Kammer, H., Bartsch, E. (1992). Nationalsozialismus. Begriffe aus der Zeit der Gewaltherrschaft 1933-1945.

Kater, M.H. (2005). Hitler-Jugend. Aus dem Englischen von J.P. Krause. Berlin: Primus Verlag.

Klemperer, V. (1970). LTI. Notizbuch eines Philologen. Leipzig: Verlag Philipp Reclam, 350.

Knopp, G. (2000). Hitlers Kinder. München: C. Bertelsmann Verlag.

Koschorke, A. (2016). Adolf Hitlers „Mein Kampf“. Zur Poetik des Nationalsozialismus. Berlin\& Matthes Verlag.

Krieck, E. (1922). Philosophie der Erziehung. Jena: Eugen Diederich Verlag. 
Krieck, E. (1936). National-politische Erziehung. Leipzig: Armen-Verlag.

Kultaieva, M.D. (1988). Philosophical and Pedagogical Tendencies in the Contemporary Idealism. Kharkiv: Vyshcha shkola [in Russian].

Kultaieva, M. D. (1999). The concept «Bildung» in the German Philosophical Tradition or Thinking about Meaning and Mission of Education. Postmethodics, 1, 8-13 [in Russian].

Kultaieva, M.D. (2002). M. Heidegger in memory of his colleagues and students. In: M. Heidegger in visualization of his contemporaries. Kyiv: Stylos, 3-23_[in Ukrainian].

Kultaieva, M.D. (2006). Max Horkheimer as the Patriarch of the Frankfurt School. In: Max Horkheimer. Eclipse of Reason. Translation from German by M. Kultaieva. Kyiv: PPS2002 [in Ukrainian].

Kultaieva, M.D. (2017). The Education and its Deformations in the contemporary culture: on actuality of Th. Adorno's theory of Half-Education in the modern social and cultural contexts. Filosofiya osvity. Philosophy of education, 1(20), 153-195 [in Ukrainian]. URL: www.philosopheducation.com

Kunkel, M. (2014). Perspektiven der Forschung und der Erinnerung an den Nationalsozialismus. In: Gedenken und Weiterdenken. Hrsg. Matthias Wagner. Lüdenscheid: GeDenk-Zellen Altes Rathaus Lüdenscheid, 96-113.

Leske, M. (1990). Philosophen im Dritten Reich. Studie zu Hochschul - und Philosophiebetrieb im faschistischen Deutschland. Berlin: Dietz Verlag.

Liessmann, K.-P. (2002). Günter Anders. München. Beck.

Mann, T. (2009). Betrachtungen eines Unpolitischen. Frankfurt am Main: Fischer Verlag.

Martynkewicz, W. (2011). Salon Deutschland. Geist und Macht 1900-1945. Berlin: Aufbau Verlag.

Mommsen, H. (1991). Der Nationalsozialismus und die deutsche Gesellschaft. Hamburg: Clett.

Reckwitz, A. (2017). Die Gesellschaft der Singularitäten. Zum Strukturwandel der Moderne. Berlin: Suhrkamp.

Reimann, B.W. (1986). „Die Selbst-Gleichschaltung“ der Universitäten 1933. In: Hochschule und Wissenschaft im Dritten Reich. Hrsg. J. Trödler. Frankfurt a. M.: Suhrkamp, 38-52.

Spranger, E. (1928). Das deutsche Bildungsideal der Gegenwart in geschichtsphilosophischer Beleuchtung. Leipzig: Quelle und Meyer.

Schlegelmilch, A. (2014). Perspektiven der Forschung und der Erinnerung an den Nationalsozialismus. In: Gedenken und Weiterdenken. Hrsg. Matthias Wagner. Lüdenscheid: Ge-Denk-Zellen Altes Rathaus Lüdenscheid e.V.

Schmidt, H., Stern, F. (2010). Unser Jahrhundert. Ein Gespräch. München: C.H. Beck Verlag.

Schmitt, C. (1933). Staat, Bewegung, Volk. Die Dreigliedrigkeit der politischen Einheit. Hamburg.

Schmitt, C. (1979). Geistesgeschichtliche Lage des heutigen Parlamentarismus. Berlin: Insel.

Sloterdijk, P. (2015). Die schrecklichen Kinder der Neuzeit. Berlin: Suhrkamp.

Tillich, P. (1980). Die sozialistische Entscheidung. Berlin: Medusa.

Trawny, P. (2014). Heideggers philosophisches Erbe steht auf dem Spiel. In: Philosophie Magazin, 03, 72-74. 
Wolin, R. (2014). Heideggers jüdische Schüler. Im Namen des Meisters. In: Philosophie Magazin, 03, 78-79.

Zichy, M. (2017). Menschenbilder. Eine Grundlegung. München.

Мария Култаева. Философия воспитания Третьего рейха: политико-идео-
логические контексты и концептуальные конструкты
В статье анализируются теоретические корни и социально-политические контексты становлення философии образования и воспитания Третьего рейха на широком текстологическом материале и с использованием нарративных интервью, проведенных автором с включенными наблюдателями данного процесса. Предлагается сравнение национал-социалистической философии воспитания и теории коммунистического воспитания. Уточняется роль политической романтики в этом процессе, а также прослеживаются её образовательные и воспитательные импликации в рамках, заданных идеологией национал-социализма. Выясняются особенности конструирования образа «нового немецкого человека на основе ницшеанства и расовой теории. Осуществлена реконструкция тоталитарного педагогического и философско-антропологического мышления в идеологических фреймах национал-социализма. Показаны патологии, возникающие на основе изменений общественного сознания и психологии соцумов, которые имеют мощный иллюзиогенный потенциал, где идеология выступает как эрзац религии. Раскрываются новые аспекты национал-социалистической философии образования и воспитания, а также педагогических практик, которые существовали в Германии в начале XX в., обусловленные стремлением реанимации домодерных представлений о смысле и предназначении образования, а также попытками рефеодализации общественной жизни на основе постсекулярных идеологем. Критически анализируются концепции национально-политического воспитания и народно-политической антропологи (Э. Крик), политической педагогики и проектов реорганизации научного производства (А. Боймлер), а также системы образования, ориентированной на образ «фюрера» и на идеал «воспитательного государства». Раскрывается внутренняя противоречивость требований расширения самостоятельности молодежи, доминирования функционального воспитания и стратегии самоподключения немецкого университета, а также мифотворчества в проблемном поле образования и культуры. Философия образования и воспитания Третьего рейха с ее претензиями на обновление общественной жизни является модерной Криминальной утопией с ограниченной вариативностью и негативной верификацией.

Ключевые слова: философия образования, национал-социализм, политическое воспитание, политическая педагогика, фюрер, раса, студент, школа, университет. 


\section{Maria Kultaieva. Philosophy of Education of the Third Reich: origin, political and ideological contexts and conceptual constructions}

The article proposes the analysis of the development of the philosophy of education in the Third Reich, including its theoretical origin with corresponding social, cultural and political contexts. The leading role of the political romantics is showed in this process with its educational implications. This research has a wide-spread empirical background including narrative interviews with the former participants of the educational processes which are described both on the factual and interpretative level. The semantics and linguistic preferences of national-socialism used in its philosophy of education show the pedagogical intentions grounded on the race theory. The "folk view of world" in the period of the national-social movement was later changed into the philosophy of political education and folk-political anthropology (E. Krieck), where the concept folk community with its leader (Führer) is a constitutive one and the functional education has become a priority before the intentional strategies. The deformation of bourgeois human ideal through returning to the myth of origin and Nietzsche's concept of the superman is remarkable in the new contrary ideals of "the Soldier" (A. Baeumler) and the "Worker"(E. Jünger) used in the educational practices of the national-socialism with the priority of the functional education. The identification of the "soldier way of life" as the representation of Nordic race with the pedagogical reality had consequences in the curriculum philosophy of schools and universities, where the physical education and the race theory have displaced the traditional subjects studies and their research fields, especially after their synchronic switching on the totalitarian state, which must understand itself as the educational one created for the German race.

The national-socialist political pedagogic has the features of the "total mobilization" for the total war as the free decision of young men ready to die for Hitler's Germany. Emphasizing of the self-activities, self-control, self-aid and self-education in the national-pedagogical directives is connected with the utopian dream of automatically fulfillment of all educational plans with the intention to create a new human for the new society. The new schools organized under national-socialism have showed the regress in comparison with educational institutions of the Weimar republic, where the educational system has showed more variety and flexibility as the chaotic improvisations of the educational reformers of the Third Reich with their fiction of the educational philosophy, which was only the well-known maid of the new political theology.

Key words: philosophy of education, national-socialism, political education, political pedagogic, leader, race, student, school, university.

Култаєва Марія Дмитрівна - доктор філософських наук, професор, член-кореспондент НАПН України, завідувач кафедри філософії, Харківський національний педагогічний університет імені Г.С. Сковороди, Президент Українського товариства філософії освіти, перекладач україн- 
ською праць сучасних зарубіжних філософів (У.Бек, В.Вельш, Г.Гадамер, Ю.Габермас, Г.Йонас, Р.Рорті та ін.).

E-mail: shepitko@hotmail.com

Maria Kultaieva, Doctor of philosophical sciences, Professor, Corresponding Member of the National Academy of Educational Sciences of Ukraine, Chief of philosophy department, H.Skovoroda Kharkiv National Pedagogical University, President of the Ukrainian Philosophy of Education Society, Translator of contemporary foreign philosophers' books into Ukrainian (U.Beck, W.Welsch, H.Gadamer, J.Habermas, H.Jonas, R.Rorty etc.).

E-mail: shepitko@hotmail.com 